\title{
Inflation in Theory and Practice
}

The eCONOMIC EXPERIENCE of the past decade has confirmed the limitations of stabilization policy for slowing inflation. The two recessions of the decade revealed how costly it is to stop an entrenched inflation by creating economic slack. Two episodes of massive increase in energy prices exposed the vulnerability of the average price level to exogenous supply shocks. And the economy's performance throughout the decade frustrated attempts to combine price stability with goals for high employment that are conventionally accepted and that are based on observations of the labor market.

The failure to stop inflation during the past ten years contrasts starkly with the success achieved in reducing unemployment during the 1960s. As a consequence, professional macroeconomics has been in ferment throughout the past decade. In contrast to the broad consensus that existed ten years ago about stabilization, today there is substantial disagreement about how to deal with inflation and about the costs of alternative strategies for slowing it. The predominant way of thinking about this problem is based on an economy with quantity-adjusting markets and involuntary cyclical unemployment. Within this neo-Keynesian model of the macroeconomy, a Phillips curve represents the short-run response of wage inflation to cyclical variations in unemployment. Most prices are largely determined by the costs of inputs, the most important of which is labor. But the response of the average price level to cyclical fluctuations is magnified by the movement of volatile raw materials prices and by a

I am grateful to members of the Brookings panel for helpful discussions and to J. Edward Shephard for research assistance. 
small cyclical response of price-wage margins. The model also takes account of inertia in wage inflation and of some feedback from prices back to wages. Exogenous shocks to prices or wages are additive to the price or wage change generated by the Phillips curve-inertia mechanism. And movements in exchange rates affect domestic prices insofar as they do not simply compensate for inflation differentials. I have previously referred to this general description of the inflation process as a mainline view. ${ }^{1}$

An alternative view of the macroeconomy comes from the "new classical" or "pre-Keynesian school." It is rooted in a world of price takers and only transitory departures from full-employment equilibrium. Although rational expectations are neither necessary nor sufficient for most of its results, this new classical school is closely identified with the macroeconomic literature based on rational expectations about prices. In that literature, the observed Phillips curve reflects quantities fluctuating in response to unanticipated disturbances to prices. If price movements are anticipated, output will not depart systematically from its equilibrium path, and unemployment will not depart systematically from some natural or equilibrium rate. In most versions of these new classical models, unanticipated changes in prices come from monetary surprises. Expected changes in money are fully reflected in corresponding changes in the average price level and have no effects on output or employment.

The gradual buildup of inflation during the 1960s was well predicted by the mainline models and their cyclical Phillips curves. The failure of inflation to slow in the face of recession required important amendments to take account of the inertia in inflation as well as improved measures of labor market tightness. The new classical models cannot readily explain the sustained decline in unemployment that characterized the 1960 s, except by defining it as a continual decline in the natural unemployment rate; and they require a continual upward revision of the natural unemployment rate to explain the failure of inflation to slow in the early 1970s. The mainline models correctly anticipated the effects of the OPEC oil price increase on inflation and unemployment and correctly predicted the stagflation that followed. These developments were incorrectly predicted by the new classical models that presume price flexibility. Thus the new classical economics has not been supported by its ability to

1. George L. Perry, "Slowing the Wage-Price Spiral: The Macroeconomic View," $B P E A, 2: 1978$, pp. 259-91. 
predict or explain the economic developments of the past two decades, nor even by any gross failures of the mainline models to explain those developments once the great inertia of inflation in the 1970s is allowed for. However, the inflation equations of mainline models have not been empirically stable. The movement up to a new plateau in wage inflation after the 1960s is imperfectly understood. And there remain unsettled analytic questions within the mainline framework concerning the inflation process and the response of inflation to policy actions.

In this paper I present a model of wage inflation that stays within the general mainline framework; but by explicitly describing the wage-setting process that underlies macro inflation, it arrives at an empirical characterization of inflation that is different from past work. That empirical model is supported by the data on inflation, especially the developments of the past decade. ${ }^{2}$ The wage-setting model is based on the codetermination of wages and employment at the level of the firm. It distinguishes sharply between two parts of the wage-setting process: one that gives rise to the cyclical Phillips curve and one that gives wage inflation its persistence. The model makes no use of the concepts of a natural unemployment rate and acceleration in explaining wage inflation and implies that the use of these concepts in empirical work during the past decade has been inappropriate and misleading.

After presenting the wage-setting model, I review the inflation of the past decade and then provide empirical estimates of wage inflation based on the model and informed by developments of the 1970s. Monetarist models and, even more, new classical models, take a different view of inflation and the macroeconomy than the one developed here. I then examine some evidence on the performance of these models in explaining inflation. I conclude by comparing remedies for inflation.

\section{Inflation with Keynesian Unemployment}

Inflation in the model of this paper is an extension of the Keynesian analysis of real activity. The defining characteristic of Keynesian unem-

2. I do not consider price inflation separately, although the effect of prices on wages is part of the model. Apart from fuel prices, which have been dominated by OPEC, U.S. price regulations, and food prices that have moved in response to crop conditions and the beef cycle, price inflation in the U.S. economy has been closely determined by wage inflation, See, for instance, Robert J. Gordon, "Can the Inflation of the 1970s be Explained?" BPEA, 1:1977, pp. 257-64. 
ployment is that qualified people who want jobs at the going wage are out of work while others are underemployed. It is the inflationary process in this situation that I want to model because it is the situation that usually exists. ${ }^{3}$

As the overall labor market tightens, unemployment in some segments of the market approaches the frictional or structural limits associated with optimal job search and shifting employment needs among firms. If unemployment at frictional or structural levels is taken to define a natural unemployment rate, then there would be no unique natural rate in a heterogeneous labor market but a broad zone within which more and more segments of the market approach their natural rate. Time enters into the concept, for as the labor market tightens in some segments, firms restructure their job requirements or invest in training in order to employ workers from other segments. We may have been in this zone by the end of the 1960s. The present model does not reject the concept of a natural rate understood in this way. It does reject the idea, common in models of the past decade, that a natural rate can be identified conceptually with the point at which inflation worsens or improves, or can be discovered empirically by simple manipulations of a Phillips curve. Inflation is a by-product of the process by which wages and employment, at the level of the firm, are codetermined; and it can worsen with widespread Keynesian unemployment, well short of any natural rate zone.

I will not review the extensive recent literature explaining the existence of Keynesian unemployment by showing that it is not optimal for firms to cut wages in order to clear the labor market. ${ }^{4}$ And I will make use of Arthur Okun's characterization of the job market as one in which most firms maintain fairly long-term career relationships with their work-

3. The modern analysis of flows through employment and unemployment blurs this concept but does not destroy its point for the present purpose. In an economy with Keynesian unemployment, many workers hold jobs that are inferior to those for which they are qualified; and both the number and duration of unemployment spells are above frictional levels. This situation is not explainable by a misperceptions model of search theory wherein unemployment exists above a frictional level only until workers learn what job offers are truly available.

4. Baily pioneered the contract theory of sticky wages as an outgrowth of risk aversion. Okun emphasized the long-term ties between workers and firms. See Martin Neil Baily, "Wages and Employment under Uncertain Demand," Review of Economic Studies, vol. 41 (January 1974), pp. 37-50; and Arthur M. Okun, "Inflation: Its Mechanics and Welfare Costs," BPEA, 2:1975, pp. 351-90. In his paper in this issue, Robert E. Hall develops in depth the case for sticky wages and presents numerous other references. 
ers. Employment arrangements involve implicit contracts between firms and their workers that translate most of the variation in demand that firms experience into variations in employment rather than wages. The explicit contracts of collective bargaining are, for this purpose, a special case of implicit contracts, although at times they may be especially important in the behavior of overall wages. In 1970, 28 percent of the private nonfarm wage bill came from wages covered by major collective bargaining agreements, although that percentage has declined steadily since.

A part of the labor market operates more nearly as an auction market, with wages relatively sensitive to the firms' employment needs and to the state of the labor market. Wages in this part of the market are nonetheless influenced by wage levels in general, either through competition for workers with given qualifications or through the minimum wage that is related to average wages in the economy. This sector cannot clear the entire market because it is too small a part of the total and because many people normally confine their job seeking to firms and sectors having implicit or explicit contracts.

\section{THREE SOURCES OF WAGE CHANGE}

In this job market there are three distinct economic processes that potentially act on wages. One is the response of average real wages to Keynesian unemployment and changes in demand. In the usual static models, the real wage must fall in order to reduce the level of Keynesian unemployment. In fact, the real wage expressed in terms of the price of output produced by labor shows no systematic cyclical movement. This persistent empirical fact means that real wage variation is unimportant in modeling the economy's cyclical behavior. ${ }^{5}$ More fundamentally, the inflation process takes place in terms of nominal rather than real wages.

5. On this point, there is agreement with Robert Lucas in his attempt to model the cycle as an equilibrium phenomenon. See Robert E. Lucas, Jr., "Understanding Business Cycles," in Karl Brunner and Allan H. Meltzer, eds., Stabilization of the Domestic and International Economy, Carnegie-Rochester Conference Series on Public Policy, vol. 5 (Amsterdam: North-Holland, 1977), p. 17. However, models of search theory have sometimes been expressed in terms of real wages, producing the classical result that unemployment departs from a natural unemployment rate only through misperceptions of prices. Within the mainline framework, the Phillips curve is sometimes modeled as a relation in real rather than nominal wages. This seems to imply that real wages are higher with lower unemployment, contrary to the Keynesian static model. 
Prices may be a factor influencing nominal wages. But it is the process by which nominal wages are determined that is central to explaining wage inflation.

The process of nominal wage setting has two distinct parts. The first is the response of nominal wages to unemployment and demand. This is the cyclical part of the model and is based on relative wage changes that accompany changes in employment at the level of the firm. It is central to how labor resources are allocated and generates the part of the inflation story associated with the short-run Phillips curve. The second is the response of nominal wages in individual firms to a wage norm for the economy. By definition, the norm is unrelated to current unemployment or demand. A firm's relative wages do not change when it increases them at the norm rate, so keeping up with the norm leaves employment in the typical firm unchanged. This part of the process has no consequences for allocation, but it is an important part of the chronic inflation story.

\section{CYCLICAL WAGE CHANGES}

To analyze the cyclical part of the model, I first abstract from the effects of the norm by assuming it is zero and that average wages are initially stable. The cyclical part of the model explains the existence of wage inflation at a fixed unemployment rate and the relation between wage infiation and varying unemployment rates. It is based on the response of individual firms to changes in the demand for their product. In this response, firms adjust relative wage levels to achieve employment targets, and in this sense wages and employment are codetermined. ${ }^{6}$ Expectations of demand by firms may play some part in determining their desired employment levels. But any distinctive effect from such expectations is short-lived if they are not confirmed by actual orders or sales, so I focus on the response of firms to actual changes in demand.

Consider the case in which total employment changes. Starting from a position of Keynesian unemployment, an expansion of total real de-

6. James Tobin modeled the cyclical behavior of wages that leads to the observed Phillips curve as a response in rates of change to excess demands and supplies in individual sectors; the model has somewhat different properties than the one developed here. See $\rightarrow$ "Inflation and Unemployment," American Economic Review, vol. 62 (March 1972), pp. 1-18. 
mand will lead to higher aggregate employment and lower unemployment. At the level of the firm, this expansion will, in general, lead to a rise in wages offered by some firms that need to attract workers. If the demand increase is concentrated among high-wage firms that workers are eager to join, there may be no wage increase there; but increases may then be needed among low-wage firms, some of whose original workers switch to better jobs. ${ }^{7}$ Following these initial increases among firms that must raise wages to attract employees, there may be subsequent increases in wages at other firms designed to restore initial relative wage patterns. Such subsequent adjustments will lead to some effect on wages from lagged unemployment. But there are two reasons why this next step in the process does not lead to acceleration.

First, the need to restore relative wages may be weak or even nonexistent in a position of Keynesian unemployment. In particular, highwage firms do not respond to all cyclical increases in wages of low-wage firms. The ability of many wage-setting firms to expand employment at their current wage implies that they need not chase the first relative wage increase upward. Such behavior is consistent with any model that accepts the presence of unemployment without market-clearing wage changes in the first place.

Empirical evidence shows that relative wages across some sectoral decompositions of the economy have drifted apart for extended periods. I found that the gap between low- and high-wage industries closed throughout the 1960s and confirmed Wachter's earlier finding of a systematic relation between the dispersion of wage levels and the unemployment rate. ${ }^{8}$

Second, even if other wages do rise to restore the initial pattern of relative wages, those wages that increased initially need not rise again to reopen the initial gap that was needed to gain employees. The relative wage that a firm pays when it needs to expand employment should be higher than the relative wage needed to maintain the new level. Maintaining the new level simply requires avoiding excessive quits. To a first approximation, this ought to require only the relative wage that sufficed

7. Arthur M. Okun identified such cyclical job improvement as a major phenomenon in the U.S. labor market in his "Upward Mobility in a High-pressure Economy," BPEA, 1:1973, pp. 207-52.

8. See Perry, "Slowing the Wage-Price Spiral"; and Michael L. Wachter, "The Wage Process: An Analysis of the Early 1970s," BPEA, 2:1974, pp. 507-24. 
at the firm's initial employment level. Thus catch-up of other wages, with the new lower unemployment rate maintained, would not in turn require a corresponding further increase of the wages that rose initially.

In principle, the cyclical wage behavior in the simple deterministic model I have just described not only is stable rather than accelerationist, but eventually is not inflationary at all so long as the economy remains within the region of Keynesian unemployment. Some relative wage adjustments propagate the initial wage increase for a while, and these effects may be quantitatively important. But analytically, they disappear in time.

The further elaboration of the cyclical story depends on the stochastic nature of demand among sectors that Tobin has emphasized. ${ }^{9}$ Even if total employment does not change, shifting demand leads to the need to expand employment in some sectors while it is declining in others. If firms operated in auction-like markets with flexible wages, the employment loss of one firm would just offset the gain of another, and the pressure of the two on the common auction-market wage would also be offset. But in contract markets, that symmetry does not hold. Expanding firms may increase wages to attract employment, while their declining counterparts hold the line on wages and reduce employment through normal attrition or layoffs. Through such an asymmetry the constant shifting of demand can keep wage inflation alive, even confining our attention to the cyclical part of the model, and still ignoring the effects of the wage norm.

The mechanism just described makes wage changes, $w$, depend on both the rate of unemployment, $U$, and the change in employment, $e$, or on unemployment relative to that rate. The pool of workers available to a firm that wants to expand employment is proportional to, although not limited to, the unemployed. If the optimal wage increase depends on the employment increase desired as a fraction of the available labor pool, the wage behavior for the typical firm that needs to attract additional workers is given by

$$
w_{i}=f\left(\frac{e_{i}}{U}\right),
$$

where here and throughout this paper variables in lowercase letters are percentage changes, and the $i$ subscript indicates a disaggregated variable. When this relation is aggregated, if total employment does not deviate

9. Tobin, "Inflation and Unemployment." 
from a trend, the expected sum of the $e_{i}$ will not contribute to explaining the variance in $w$, and the familiar aggregate relationship between wage changes and the inverse of the unemployment rate emerges:

$$
w=g\left(\frac{1}{U}\right)
$$

If total employment and unemployment change, the part of the sum of the $e_{i}$ that departs from trend will appear when the responses of firms are aggregated so that the change in employment or unemployment relative to the level of unemployment will be an additional determinant of aggregate wage changes:

$$
w=h\left(\frac{1}{U}, \frac{\Delta U}{U}\right) .
$$

It would seem natural to test the importance of employment changes in the cyclical inflation process using disaggregated data. However, if firms hire new workers into the bottom part of wage scales, the firms' average wage may decline when employment expands even if their wage offers are raised at every point in their wage scales. This possibility also introduces a problem for estimation with aggregates. Furthermore, if employment varies primarily in high-wage durable goods industries while the wage pressure is created in other industries paying lower wages, the connection between employment changes and wage changes at the firm or industry level will be lost or even appear perverse. This problem will not appear in aggregate analysis explaining a wage index adjusted for relative industry shifts because aggregate employment increases will be properly correlated with wage increases.

\section{THE WAGE NORM}

The cyclical model outlined above explains all the Phillips curve characteristics of the economy but only a part of the inflation story. The other part comes from what I once called the "habitual" rate of wage increase. I now prefer Okun's term of the "norm" rate of wage increase because it conveys the idea of a standard that can be affected by a range of developments and not simply by what has become habitual, although that is bound to be a major part of it. The observed behavior of wages comes from both these determinants: the ongoing wage inflation asso- 
ciated with the norm and the relative wage changes associated with adjusting employment in response to firms' demand for labor.

This distinction between the two forces acting on nominal wages is not just a way of splitting one process underlying wage behavior into two parts. The cyclical mechanism describes the response of wages to the state of labor market tightness and to changes in real demand among sectors and in the aggregate. All the allocative functions of wage changes are included in that mechanism. The norm describes the trend of wage behavior independent of these real demand effects. Keeping up with the norm is the neutral standard expected under the implicit contracts that dominate wage setting. And keeping up with the norm is the allocatively neutral wage strategy for individual firms; it neither improves nor worsens their positions as employers.

When the norm and cyclical mechanisms are combined, the total effect on wage inflation will depend on how the norm responds to actual wage developments. But some analytic properties can be inferred without fully specifying that response.

Distinguishing the norm from cyclical effects on wages does not imply that the norm is insulated from the effects of demand. The norm for wage increases is at least partly an adaptive response to past rates of wage increase. Thus a sustained wage inflation that arises from reducing unemployment will eventually escalate the norm as it did in the late 1960s. But if the economy is still in the region of Keynesian unemployment so that the cyclical mechanism is not accelerationist, adding the effects of the norm will not make the process accelerationist.

Once unemployment has stabilized at its new low level, the cyclical mechanism predicts that wage inflation, apart from the norm, will gradually settle back to the stable rate generated by stochastic shifts in demand among firms. This stochastic component should itself generate only small, and possibly zero, average rates of wage increase. Actual wage inflation will gravitate to the sum of this low rate and the new higher norm resulting from the actual wage inflation that was experienced as unemployment declined. The part of average wage increases coming from the stochastic component does not gradually feed into the norm and escalate it further, because all firms and sectors take turns at raising their relative wages in this stochastic process.

In actual experience the effects of the norm and of changes in the norm will be comingled with cyclical effects acting on wages and employment. 
Especially if it takes some time for changes in the norm rate of wage increase to permeate wage setting throughout the economy, the data will not be able to sort out accurately the separate influences on wages. A transition to a new norm for wage increases will be hard to track. But when it is completed, the cyclical response of wages should be observable around the new norm.

The interaction of the norm and cyclical effects can contribute to ratcheting up inflation over time. Firms that value long-term employment relationships have a stake in being known as "a good place to work." In setting wages, such firms may be more anxious about missing an increase in the wage norm than about responding too slowly to a decrease. Because the norm will turn out to be what the aggregate of firms makes it through their own behavior, it thus may rise with cyclical expansions more readily than it falls with cyclical contractions.

\section{ESTABLISHING THE NORM}

In empirical work, both my own and that of most others, the inertia in inflation has generally been estimated through a lagged dependent variable. One problem this can produce is discussed below in connection with estimating a natural unemployment rate. For the model presented here, this procedure implies a continuous adjustment of the wage norm to actual wage changes and to nothing else. And that implication is inconsistent with the sharp discontinuities between estimates of the effect of the lagged dependent variable in regression equations that end in the 1960s and those that end in the 1970s. This difficulty in using the lagged dependent variable is predicted by the present model in which changes in the norm are episodic rather than continuous, and in which the norm can be affected by other developments besides past wage changes.

One reason for a more complicated relation is that wage developments that are part of the normal cyclical pattern of relative wages may have little effect on the norm. Wage inflation in high-wage industries may be largely unaffected by the speedup in wages in low-wage industries that occurs in cyclical upswings. It may also be unaffected by changes in the minimum wage. Conversely, the pay in low-wage sectors may be largely unaffected by increases that major unions obtain. In general, some systematic changes in relative wage levels are part of the cyclical story. But they will influence the norm rate of wage inflation only as they contribute to a sustained rate of actual wage inflation. 
Another reason for believing the norm is not related in a simple way to actual wage changes is that brief departures of actual wages from the prevailing norm do not seem to matter. Before the 1970s, a cyclical Phillips curve reflecting a wage norm roughly consistent with price inflation of 1 percent explained wages adequately. As I suggest below, one can improve the fit slightly by allowing for a downward shift in the norm between the 1950s and the 1960s. But any such shift must have been small. And judging from how well simple Phillips curves fit the late 1960 s, the norm changed only gradually, if at all, for several years after actual inflation became a prominent fact in the middle of the decade. Finally, the wage explosion that followed the end of controls in the first quarter of 1974 did not become a new norm for wages.

The norm may also be affected by price changes that are independent of wage changes. The implicit contracts that govern wage setting may be influenced by the path of real wages even if the cyclical response of wages to demand is entirely a relation in terms of nominal wages as I have modeled it here. Thus, although the exogenous price explosions arising from the two OPEC price increases of the 1970s did not pass promptly or fully into wage inflation, the considerable deterioration of real wage gains that resulted may have gradually lifted the norm rate of wage increase above what it would have been otherwise.

Finally, the norm may be influenced by direct policies of the government such as wage guideposts, controls, or standards associated with reward or penalty schemes of various tax-based incomes policies. In principle, the norm may also be responsive to credible policies affecting expectations of future wage changes along the lines that William Fellner has advocated. ${ }^{10}$ The norm undoubtedly reflects expectations of the rate of wage inflation throughout the economy; but in the normal course of things, those expectations are formed largely on the basis of experienced inflation, not pronouncements about aggregate demand policy. In general, because it is a force acting on wage inflation that is separate from the cyclical forces of demand, any programs to change the norm directly while also allowing for relative wage changes around the norm can operate without distorting any allocative functions of the wage-setting process. Guideposts linked to tax-based incomes policies have this desirable characteristic.

10. William Fellner, Towards a Reconstruction of Macroeconomics: Problems of Theory and Policy (American Enterprise Institute, 1976), pp. 116-18. 


\section{Inflation and the Natural Rate}

The inflation process I have described operates without reference to a natural rate of unemployment. A natural unemployment rate is one characteristic of classical equilibrium. And acceleration of inflation at unemployment rates below the natural rate is a central characteristic of new classical theories. But these concepts have also been used widely to describe developments of the 1970s by economists who do not accept the macroeconomics described by those theories. The concepts have been tacked onto empirical Phillips curve models without any rigorous derivation of how they fit in or why they belong there.

In particular, it has become commonplace to assume that lagged inflation enters a Phillips curve equation with a coefficient of 1.0 and to identify the natural rate of unemployment, $\bar{U}$, by solving constrained empirical Phillips curves for the unemployment rate that implies nonaccelerating inflation. That is, if

$$
w=A_{0}+a_{1} \frac{1}{U}+w_{-1}
$$

the nonaccelerating inflation point, identified as the natural or nonaccelerating unemployment rate, is $\bar{U}=-a_{1} / A_{0}$. Furthermore, from the accelerationist equation 1 and the definition of $\bar{U}$ it follows that

$$
w-w_{-1}=a_{1}\left(\frac{1}{U}-\frac{1}{\bar{U}}\right) .
$$

Thus if wages rise faster this period than last, the economy must be in the accelerating region and unemployment must be below its natural rate in these models.

None of these properties fits easily into a mainline model with Keynesian unemployment. The inflation model developed in this paper generates inflation, but not automatic acceleration, over a range of unemployment rates. And it identifies this inflation with the process of declining unemployment as well as with a maintained level. In this model, inflation can exist and can be faster this period than last without indicating that a crucial unemployment rate has been passed or that inflation will continue to accelerate if this period's unemployment rate is maintained. 


\section{The 1970s}

The inflation story during much of the 1970s comes from outside the general model of wage changes I have outlined. Control, decontrol, and explosive increases in food and fuel prices are exogenous to the cyclical inflation process and to the existing wage norm. Before presenting empirical estimates of the wage model, I first describe the major developments of the period and suggest how the norm may have been changing in these years.

\section{LEAVING THE 1960S PHILLIPS CURVE}

The 1970s began with aggregate wage inflation running well above the rate predicted by the Phillips curve that had fit so well through the previous two decades. This failure of wages to decelerate as unemployment rose had two elements. Wages set in major union negotiations accelerated sharply; and the norm for wage setting elsewhere in the economy adapted to an environment of chronic inflation. These two elements undoubtedly reinforced each other. But the behavior of union wages was sufficiently different from that of other wages that it is worth examining separately.

Table 1 summarizes the wage developments of the key transitional years, 1968-71. The data on "other wages" was derived by removing the impact of effective major union wage changes from the average hourly earnings index. ${ }^{11}$ The special role of major union wages in this period stands out clearly. After rising no faster than other wages during most of the 1960s, wage increases under current settlements jumped to 9.3 percent in 1969 and to 11.9 percent and 11.7 percent in 1970 and 1971 , respectively. These settlements, together with larger increases in subsequent years under the new contracts and bigger increases from

11. The calculation is inexact because the relative importance of effective union wage changes in the total wage bill can only be estimated. Scale wages are available. The trend of average weekly hours was assumed to be forty. And trend employment was estimated to be 95 percent of workers covered by major union contracts. The major union wage bill calculated from these estimates was subtracted from the total wage bill calculated for nonsupervisory workers in the private nonfarm economy, adjusted to remove cyclical fluctuations. In 1970, within this aggregate sector 28 percent of the wage bill and 23 percent of employment came from major union jobs. 
Table 1. Wage and Consumer Price Inflation in the Transitional Years, 1968-71'

Percent

\begin{tabular}{lrrrr}
\hline \multicolumn{1}{c}{ Measure } & 1968 & 1969 & 1970 & 1971 \\
\hline Wages in major unions & & & & \\
$\quad$ Current settlements & 7.4 & 9.3 & 11.9 & 11.7 \\
Effective wage change & 6.0 & 6.5 & 8.8 & 9.2 \\
Other wages & 7.3 & 7.0 & 5.8 & 6.3 \\
All wages (average hourly earnings index) & 6.7 & 6.8 & 6.6 & 6.7 \\
Consumer price index & 4.7 & 5.7 & 5.6 & 3.5 \\
\hline
\end{tabular}

Source: U.S. Bureau of Labor Statistics.

a. Calculated as percent changes from the fourth quarter a year earlier.

b. The increases for "other wages" were obtained by removing the contribution of effective wage changes in major unions from the increase in all wages given by the average hourly earnings index, as described in text note 11 .

cost-of-living adjustments (COLAs), made effective union wage changes about 3 percentage points greater than the average increase in other wages in 1970 and 1971.

In general, union wage changes are not the main driving force behind wage inflation. There is no consensus about any systematic causality either to or from unions beyond the immediate effect of union wages on other wages in the same firm or industry. ${ }^{12}$ During the 1950 s, union wages rose faster than the average for the economy. The union wage explosion that began in 1969 came at the end of a decade of increases that were, by contrast, no better than average, and that had slowed the historical increase in real wages of major unions. But although it may be explained by past events and relationships, this explosion happened to take place during the softening labor market conditions of the 1970-71 recession. That timing helped offset the slowdown in average wages that would have been expected from the recession, and may have helped pull up the wage norm for the economy.

How much the union wage explosion influenced other wages in those years is impossible to say. Close ties exist between some union wages and the wages of nonunion workers in the same firms and workers in nonunion firms in the same industry. The implicit contract in these cases includes an understanding that particular relative wages will not get far out of line. If some allowance is made for induced increases in these

12. See, for example, Robert J. Flanagan, "Wage Interdependence in Unionized Labor Markets," BPEA, 3:1976, pp. 635-73; and Daniel J. B. Mitchell, "Union Wage Determination: Policy Implications and Outlook," BPEA, 3:1978, pp. 537-82. 
Table 2. Wage and Consumer Price Inflation in the Era of Controls and Price Explosions, 1970:2-1975:1

Annual rate, in percent

\begin{tabular}{|c|c|c|c|c|}
\hline \multirow[b]{2}{*}{ Measure } & \multirow{2}{*}{$\begin{array}{c}\text { Before } \\
\text { controls, } \\
\text { 1970:2-1971:2 }\end{array}$} & \multicolumn{2}{|c|}{ During controls } & \multirow{2}{*}{$\begin{array}{c}\text { After } \\
\text { controls, } \\
\text { 1974:1-1975:1 }\end{array}$} \\
\hline & & $1971: 2-1972: 4$ & $1972: 4-1974: 1$ & \\
\hline $\begin{array}{l}\text { Average hourly earn- } \\
\text { ings index }\end{array}$ & 7.2 & 6.2 & 6.5 & 9.4 \\
\hline Consumer price index & 4.4 & 3.3 & 9.2 & 11.2 \\
\hline $\begin{array}{l}\text { Deflator for personal } \\
\text { consumption expen- } \\
\text { ditures }\end{array}$ & 4.4 & 3.5 & 8.5 & 10.3 \\
\hline
\end{tabular}

Sources: The deflator for personal consumption expenditures is from the U.S. Bureau of Economic Analysis. The other series are from the Bureau of Labor Statistics.

closely related wages, the balance of wages slows even further than the "other wages" in table 1. Even so, it is doubtful that the balance would have been predicted from earlier relationships. The estimate for "other wages" in table 1 decelerated by only 0.7 percentage point between 1969 and 1971, despite the abrupt slowing of wages by controls in the second half of 1971.

From this evidence it is clear that the norm for wage changes had risen by the early 1970s. And it is likely that this rise in the norm was a response both to the persistent and growing inflation of the previous five years and to the explosion of union wages that started with the current settlements of 1969. In 1971 the evidence that inflation was on a new higher plateau prompted the Nixon administration to invoke a pricewage freeze and then comprehensive controls on wages and prices.

\section{CONTROLS AND THE PRICE EXPLOSIONS}

As table 2 shows, the controls clearly decelerated wages and the prices that were subject to controls. In the year before the wage-price freeze in the summer of 1971, the average hourly earnings index had risen by 7.2 percent and the consumer price index and deflator for personal consumption expenditures by 4.4 percent. All three indexes slowed by about 1 percentage point during the first six quarters of controls through the end of 1972. Although these broad indexes show that controls slowed wages and prices in parallel over these intervals, Robert Gordon's more 
detailed analysis indicates that they slightly squeezed prices relative to wages. ${ }^{13}$

At the start of 1973, and again in 1974, food prices rose sharply as a consequence of low inventories and poor worldwide crops. In the second half of 1973, the OPEC cartel drastically raised oil prices. These twin exogenous price shocks sent the price averages soaring; by early 1974 , the CPI was rising at double-digit rates. In this environment the controls program was abandoned and prices and wages throughout the economy accelerated sharply.

This episode confirmed the judgment of many that controls can only suppress inflation and that any deceleration achieved by controls will bring an offsetting acceleration when they are lifted. This judgment is not inevitable in theory. Controls or other forms of restraint can slow the wage norm without distorting relative prices or wages. And, in practice, the judgment is not confirmed by all instances when controls have been used. When controls were lifted in 1953, no price-wage explosion followed despite a relatively low unemployment rate.

In 1974, controls were abandoned because intense inflationary pressure from uncontrolled sectors made them politically untenable. Most importantly, the CPI had been rising at double-digit rates for several months because of food and fuel prices, and real wages for most workers were declining rapidly. Implicit wage contracts throughout the economy were being strained. And an attempt at relief through higher wages was inevitable once the end of controls made it legal. If controls had never been in place, the acceleration of wages and other prices would simply have started sooner.

\section{THE LATE $1970 \mathrm{~S}$}

The economy apparently came out of the postcontrol catch-up and the deep recession of 1974-75 with a norm rate of wage increase of perhaps 8 percent a year. Although unemployment remained high in the first years of recovery, actual wage inflation crept higher each year of recovery until the wage-price restraint program with its 7 percent wage guidelines was begun in late 1978 .

As table 3 shows, increases in current settlements among major

13. Robert J. Gordon, "Wage-Price Controls and the Shifting Phillips Curve," BPEA, 2:1972, pp. 385-421. 
Table 3. Wage and Consumer Price Inflation, 1976-79a

Percent

\begin{tabular}{lcccc}
\hline \multicolumn{1}{c}{ Measure } & 1976 & 1977 & 1978 & 1979 \\
\hline Wages in major unions & & & & \\
$\quad$ Current settlements & 8.5 & 7.7 & 7.8 & 7.9 \\
$\quad$ Effective wage change & 8.1 & 8.0 & 8.2 & 9.1 \\
All wages (average hourly earnings index) & 7.3 & 7.5 & 8.4 & 8.1 \\
Consumer price index & 5.0 & 6.7 & 9.0 & 12.7 \\
Deflator for personal consumption & & & & \\
$\quad$ expenditures & 4.8 & 5.7 & 7.5 & 9.9 \\
\hline
\end{tabular}

Source: Same as table 2.

a. Calculated as percent changes from the fourth quarter a year earlier.

unions slowed after 1976, when the last round of three-year contracts signed during the controls period were renegotiated. But widespread and more complete COLAs kept effective wage gains above 8 percent. The CPI accelerated more than average hourly earnings between 1976 and 1978, and rose much faster in 1979 when first food prices and then oil prices and mortgage interest rates climbed sharply.

The second big ratchet in OPEC prices was even larger than the first one that occurred five years earlier, and its impact on U.S. energy prices is now compounded by the decontrol of oil prices. In October 1979 a wage restraint program was once more virtually abandoned under the political strain of large increases in uncontrolled prices. Since that relaxation of the wage standard, wages have accelerated substantially; by March 1980 they were 8.8 percent above levels of a year earlier. The 1978-80 acceleration in the CPI may have moved the wage norm up another notch by the end of the decade.

\section{THE 1970S AND THE PHILLIPS CURVE}

I have argued above that the norm rate of wage increase drifted up substantially by the early 1970s in response to the actual inflation of previous years, was suppressed and possibly reduced by controls during the next several years, was ratcheted upward by the price explosions of 1973-74 and by the actual wage explosion that followed decontrol in the spring of 1974, and may now be moving upward again as a result of the second OPEC oil price explosion and the escalation of union wages with COLAs. 
Actual wage changes, as opposed to the norm, were affected specifically and with different timing by the impact of prices on wages when controls were lifted, by the price increases of 1978 and 1979, by the high unemployment during and after two recessions, and by the controls early in the decade and the wage restraint program that began in October 1978.

Untypically, major union wages played a major role in the behavior of economy-wide wages during the decade, first by escalating during the recession of 1970-71 and subsequently by transmitting price increases to the wage structure through COLAs more fully and directly than might have happened in their absence. But the exceptional inflation in the price indexes that has come from rising energy prices might well have affected the norm increase in wages even in the absence of unions and formal COLAs.

\section{Estimating the Wage Model}

A way of characterizing changes in the wage norm must be chosen for the purpose of estimating the model of wage inflation. The conceptual discussion of the norm provides some guidance on what kind of developments might change the norm; and the discussion of the 1970s suggests how specific developments may have affected it. Rather than try to model changes in the norm that conform closely to these known events, I have chosen the opposite course of allowing only for substantial shifts in the norm, treating it as constant for extended periods of time. I do this by allowing for a norm shift downward after 1961 and a second shift upward starting in 1970.

The first shift allows for the cumulative impact of two quick recessions separated by only an abortive recovery in the 1958-61 period. It may also capture some effect on the norm from the introduction of the wage guideposts under President Kennedy, although the intense application of the guideposts did not occur until 1964 under President Johnson and is treated separately. The second shift allows for the cumulative impact of the sustained inflation of the last half of the 1960s. Each of these shifts is modeled by a dummy variable that is 1.0 throughout the relevant period and zero otherwise. Obviously the norm did not shift so abruptly, and this representation for empirical work can hardly capture the ability 
of the concept to explain the data. Yet even this crude representation is superior to a continuous adaptive scheme: it is evidence in favor of the norm concept that lagged wage changes were insignificant when added to any of the regression equations that use the two norm shifts.

Three kinds of response from the cyclical part of the model are mixed in the data: effects from the level of unemployment, effects from the change in unemployment, and possibly some short lags in relative wage adjustments. Both current and one-quarter lagged values of $1 / U$ are used in the equations of table 4 . The expected sign on the lagged value is negative because declining unemployment leads to faster wage increases in the model. If there is some lag in the effect of the unemployment level on wages, it will interfere with identifying this separate effect from changing unemployment. In table 5, I report equations that impose a relative lag structure of $1.00,0.75,0.50$, and 0.25 on successive past values of $1 / U$, starting with the current quarter. Those equations use $\Delta U / U$ to capture the effect of changes in unemployment.

Demographic effects on unemployment are allowed for by using a demographically weighted unemployment rate throughout. The possibility that the Phillips curve rotated in the 1970s is also explored using a shift dummy on the unemployment rates for that period. ${ }^{14}$ The equations incorporate a direct effect of cost-of-living adjustments on wage changes by adding the four-quarter change in the CPI, lagged one quarter.

Finally, the effects of guideposts under President Johnson and controls under President Nixon are estimated in the equations. The guideposts are modeled by a dummy variable from 1964:1 to 1966:2; after that the airline mechanics settlement broke the wage standard, which then became ineffective in other settlements as well. As the preceding discussion of the 1970s indicates, the period of Nixon controls and the first year of decontrol cannot be explained well or even handled properly by a simple dummy variable. I thus simply dropped the quarters for the 1971:3-1975:1 period from the equations reported below. I also include equations in which the entire 1970:1-1975:1 period is omitted. These avoid both the control-decontrol period and also the early 1970 s when the norm may have been in the process of drifting upward.

14. In the table 4 equations the coefficient on $1 / U$ was systematically about twice as large as the (negative) coefficient on $1 / U_{-1}$. So the possibility of a flattening in the Phillips curve was explored using the shift dummy $\left(2 D / U-D / U_{-1}\right)$, where $D$ is 


\section{Empirical Results}

The one feature of the estimates that is most sensitive to which period is included in the equations is the size of the cyclical response to unemployment in the 1970s. When only the quarters of controls and decontrol are removed from that decade, as in equations 4-4 and 4-5, the estimated effects from unemployment are changed substantially. Compared with equation 4-3 estimated through 1969, 4-4 indicates a larger response of wages to unemployment in those years. Equation 4-5, which drops the slope shift dummy, indicates a larger response throughout the entire period, and a substantially smaller norm shift in the 1970s. It turns out that the crucial quarters are the early 1970s. When these are eliminated, the estimated effects of unemployment are much more consistent.

During the early 1970 s the transition to a higher norm was taking place while the economy was in recession. One interpretation of the estimates in 4-4 is that, in order to fit this transition period, the two shift effects from the norm and the slope are both overestimated, but with offsetting effects on predicted wages. When the transition quarters of the early 1970s are dropped in 4-6, the slope shift becomes insignificant. And 4-7, in which the slope shift does not appear, shows a response of wages to unemployment that is similar to the estimates of 4-3.

Table 5 also supports this interpretation of the early 1970s. When the transition quarters are included in 5-2, the slope shift term entirely eliminates any effect from the level of unemployment in the 1970s. When the transition quarters are dropped in 5-3, the slope shift becomes insignificant and unemployment effects are similar to those in 5-1.

The effects of changes in unemployment, as opposed to its level, are necessarily better defined in table 5 , which constrains the level to enter with some lag effects. However, the size of the level effect is similar when one compares 5-4 and 4-7 or 5-1 and 4-3.

The estimated effects of lagged consumer prices decline somewhat as the period is extended. Although this variable is intended to capture the direct effect of the CPI through explicit or implicit escalators, in the early

1.0 for the 1970 s and zero otherwise. In table 5 the slope change is explored with a shift dummy of the form $D / U$. I also explored whether the unemployment relation might have changed in a way described by $1 /(U+D)$ with similar results to those discussed here. 


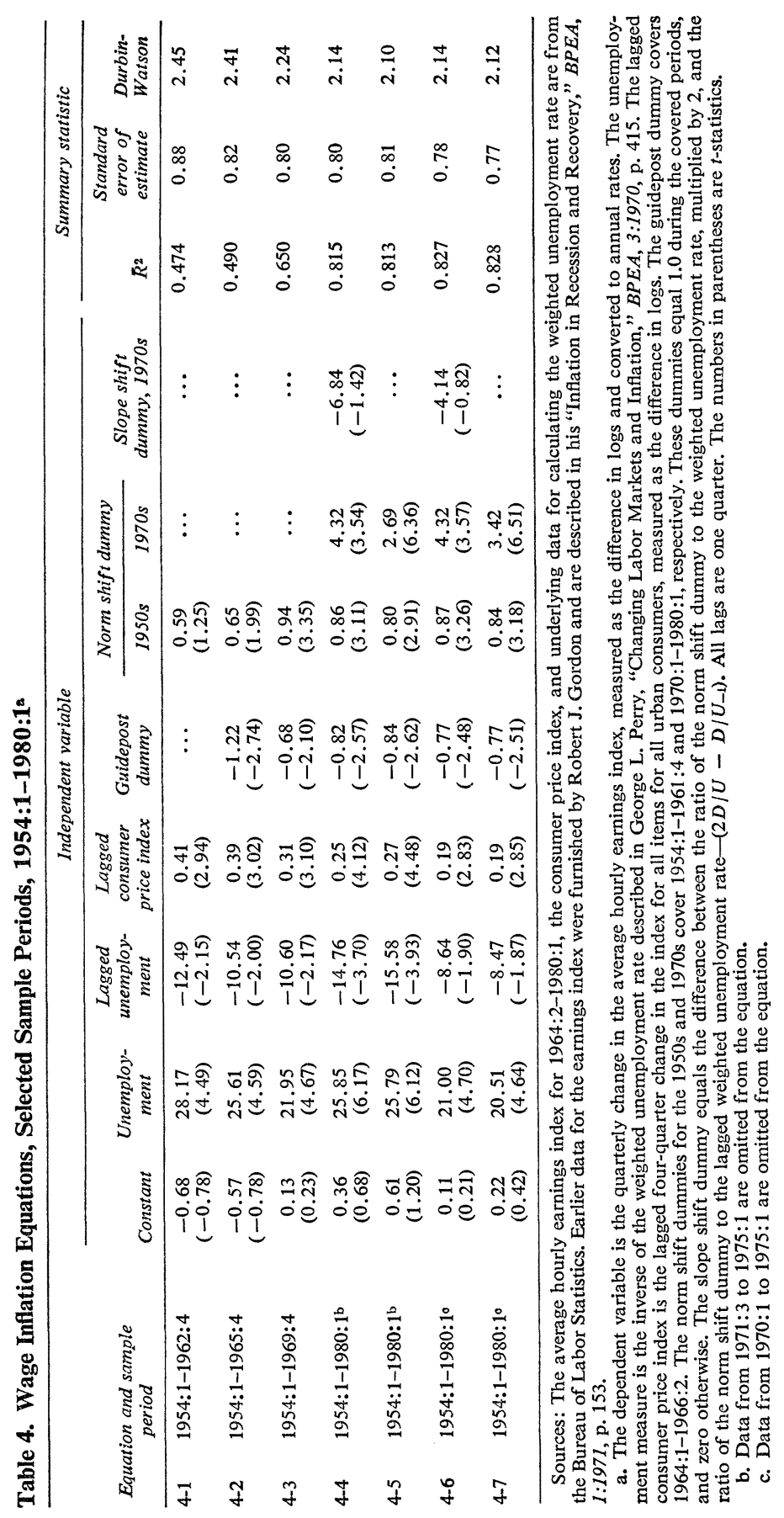




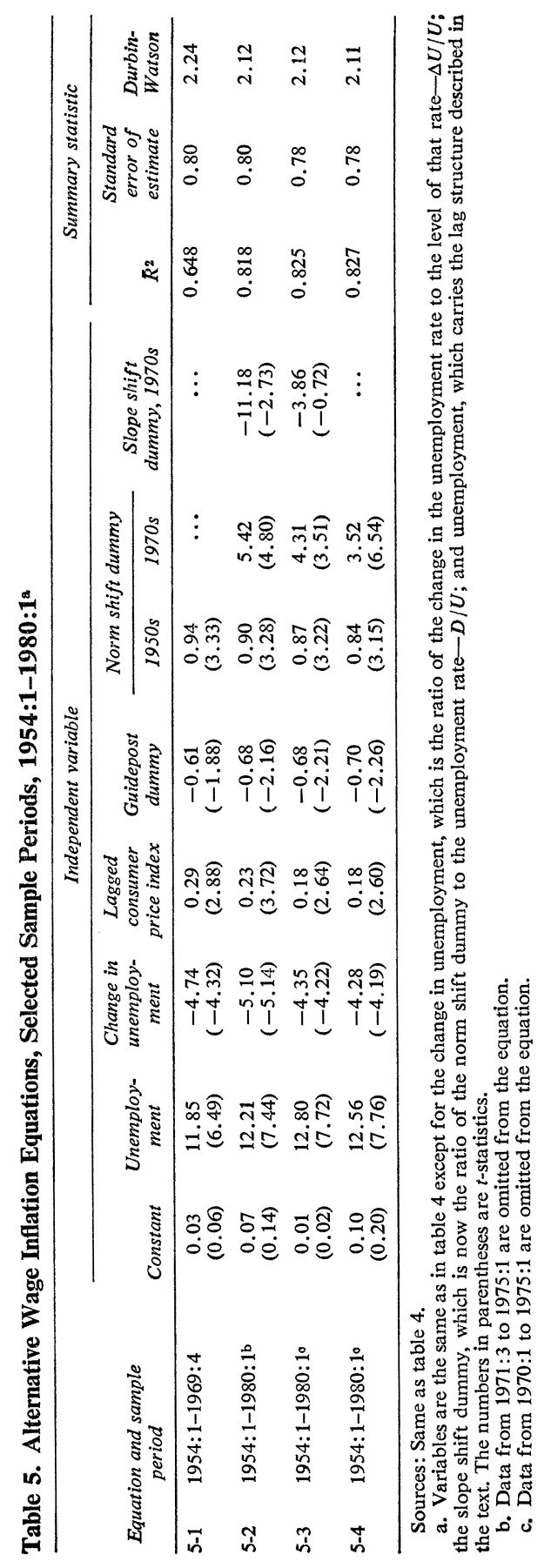


years of the sample period it also appears to be capturing some other feature of wage adjustments. Equations 4-1 and 4-2 are dominated by cyclical swings in unemployment far more than the equations fitted to longer periods. If the lagged CPI captures some structural lag in wage adjustments as well as escalator effects, its estimated effect might be larger in the equations dominated by these early years. It is unfortunate that the equations cannot capture the very short-term cyclical response of wages convincingly because there are not enough cyclical turning points in the data for the later years.

The estimated decline in the CPI coefficient between 4-3 and 4-7 may be partly due to the effect just discussed. But I can also think of two reasons for such a decline that have to do with the direct effect of escalators on wages. Although among major unions indexing became more widespread and, for modest inflation rates, more complete during the 1970 s, the proportion of wages covered by major union contracts dropped during the decade. Furthermore, most escalators are capped so that the very rapid rise in the CPI in the past few years was only partially passed onto wages through this avenue.

The indicated norm shifts from either 4-7 or 5-4 are a decline of about 0.8 percentage point after 1961 and an increase of about 3.5 points by the late 1970 s. In 4-1 and 4-2 ending in earlier years, the first shift is estimated to be smaller, so its size is not as well established. However, the substantial shift up by the late 1970 s is well established and is consistent with the model and the description of the period. The lagged dependent variable, which could represent a continuous process by which the norm is established, is not significant when added to any of the equations. And the money supply, tried with several alternative lag structures, is not significant either, indicating that the norm shift cannot be given a simple monetarist interpretation. These results generally support the description of the norm developed in the present model and in the discussion of the 1970s.

\section{Simulating Wage Inflation}

In table 6 the response of wage inflation to a deep recession is simulated using equation 4-7. The simulations begin with wage inflation constant at 9.2 percent for the year and unemployment steady at 5.7 percent. 
Table 6. Simulations of Wage Inflation with Recession

\begin{tabular}{|c|c|c|c|c|c|c|}
\hline \multirow[b]{3}{*}{ Quarter } & \multicolumn{3}{|c|}{ Sustained recession } & \multicolumn{3}{|c|}{ Recession and recovery } \\
\hline & \multirow[b]{2}{*}{$\begin{array}{l}\text { Unemploy- } \\
\text { ment rate }\end{array}$} & \multicolumn{2}{|c|}{ Rate of wage inflation ${ }^{\mathrm{a}}$} & \multirow[b]{2}{*}{$\begin{array}{l}\text { Unemploy- } \\
\text { ment rate }\end{array}$} & \multicolumn{2}{|c|}{ Rate of wage inflation } \\
\hline & & $\begin{array}{l}\text { Without } \\
\text { norm shift }\end{array}$ & $\begin{array}{c}\text { With } \\
\text { norm shift }\end{array}$ & & $\begin{array}{l}\text { Without } \\
\text { norm shift }\end{array}$ & $\begin{array}{c}\text { With } \\
\text { norm shift }\end{array}$ \\
\hline 0 & 5.7 & 9.2 & 9.2 & 5.7 & 9.2 & 9.2 \\
\hline 4 & 7.9 & 8.3 & 8.3 & 7.9 & 8.3 & 8.3 \\
\hline 8 & 9.0 & 8.0 & 8.0 & 8.6 & 8.1 & 8.1 \\
\hline 12 & 9.0 & 8.0 & 7.3 & 7.7 & 8.4 & 7.8 \\
\hline 16 & 9.0 & 8.0 & 6.3 & 6.8 & 8.7 & 7.5 \\
\hline 20 & 9.0 & 8.0 & 4.6 & 5.9 & 9.2 & 7.1 \\
\hline
\end{tabular}

Source: Derived by author from equation 4-7 in table 4 . For details of the simulations, see text discussion.

a. The rates of wage inflation are from changes in logs, expressed at annual rates.

b. The weighted unemployment rate was used in the simulations. It is expressed here in terms of its equivalent official rate.

These are the actual rates of 1980:1, although not of previous quarters. Variations in the CPI are assumed to equal variations in wage inflation during the simulations.

In the recession and recovery scenario, unemployment rises steadily by 3.3 points ( 3.0 points of weighted unemployment) during the first six quarters and then declines by 0.2 point of weighted unemployment a quarter. Without a norm shift, wage inflation declines temporarily to 8.1 percent and is back to 9.2 percent after five years. With unemployment maintained at 9.0 percent in the sustained recession, wage inflation levels off at a rate of 8.0 percent.

Especially in the case of sustained recession, the model of this paper would predict an eventual downward shift in the norm. The simulations assume the following response of the norm to actual wage developments in order to illustrate that kind of development: the norm shifts down by one-half the change in the rate of wage inflation after two years, by threefourths of the change in the rate after three years, and by the full change in the rate after four years. With sustained recession, these norm shifts reduce wage inflation to a rate of 4.6 percent after five years. If the norm remains at its new rate during a subsequent gradual recovery in which the weighted unemployment rate is reduced by 0.2 point a quarter, the rate of wage inflation would gradually rise again to about 6 percent as unemployment returned to 5.7 percent over a three-and-one-half year period. Assuming the norm shifts down according to the same formula 
in the recession and recovery scenario, wage inflation levels off at 7.2 percent by the time the initial unemployment rate is restored.

The norm shifts assumed here are conjectural. Especially in the recession and recovery scenario, the norm might not shift as much as indicated. And nothing in the past behavior of wages suggests the improvements in the norm assumed here are excessively pessimistic. Unemployment rose by more than 4.0 percentage points in the recession of 1973-75, and the subsequent recovery was about as fast as assumed here. Yet wage inflation was worse at the end of the period than it was at the beginning. Of course, as I argued above, the price explosions of 1973-74 may have pushed up the norm, thus working against the effects of slack in that case.

The cyclical response of wages to slack demand and rising unemployment is weak and makes a policy of holding back demand an extremely costly, if not futile, way to reduce inflation. If slack is not sustained so as to reduce the norm, recession leads to only a small and temporary reduction in inflation. And the plausible norm shift that is modeled here slows inflation only at a very great cost in real economic performance. In the sustained recession scenario, in addition to the high current cost of extended slack, investment incentives for business and employment opportunities for young workers would deteriorate badly, eroding the human and physical capital on which productivity depends. Any attempt to cure inflation must obviously count on the norm shifting favorably. An incomes policy of some form holds out the hope of shifting it at a more tolerable cost.

\section{Rational Expectations and Monetarism}

The model I have presented relates inflation to the established framework for analyzing real economic activity. The inflation of the past decade has also been discussed in the context of some professional literature that is very different in its approach. One part of that literature is monetarist and centers on the proposition that inflation is simply the result of excessive growth in the money supply. Another, more extensive, part of that literature has been called "new classical" and centers on models of rational expectations about prices. 
THE MONETARIST INFLATION MODEL

Any macroeconomic model will predict that faster growth of the money supply will lead to faster growth of nominal GNP, other things being equal. To a first approximation, any model will also predict that real activity is unaffected by money in the long run. Simple monetarist models are distinctive in asserting that the growth of money determines prices rather than output even in the relatively short run; and, as a corollary, that exogenous price shocks such as those experienced in the past decade primarily affect relative prices rather than the average price level except as they are accompanied by monetary accommodation.

Equations 7-1 and 7-2 in table 7 present reduced-form monetarist equations based on quarterly data for 1954-69 and 1954-79, respectively, using the specification suggested recently by John Tatom. ${ }^{15}$ The equations appear to support monetarist explanations of inflation. However, if even the simplest standard Phillips curve variables are added, as in equations 7-3 and 7-4, money growth contributes nothing to the equation. Thus there is no evidence that money growth offers a shortcut to disinflation compared with the model I have presented above.

Equation 7-4, which is fit through 1979 , is entirely unsatisfactory even allowing for the norm shift. Only the lagged dependent variable is significant. The equation fails mainly because it makes no allowance for the price shocks of the decade that I described earlier as exogenous. When $7-1$ is used to predict the annual rate of inflation in 1974, it underpredicts by an average of 7.5 percentage points. The errors from $7-2$ for this period average 5.0 percentage points.

\section{RATIONAL EXPECTATIONS MODELS}

The new classical models are often combined with monetarism. But their distinctive feature is a rejection of the established framework for analyzing the macroeconomy.

The three essential parts of the new classical theory are: the economy is a world of auction-like markets with flexible prices for both output and

15. John A. Tatom, "Does the Stage of the Business Cycle Affect the Inflation Rate?" Review of the St. Louis Federal Reserve Bank, vol. 60 (September 1978), pp. 7-15. 


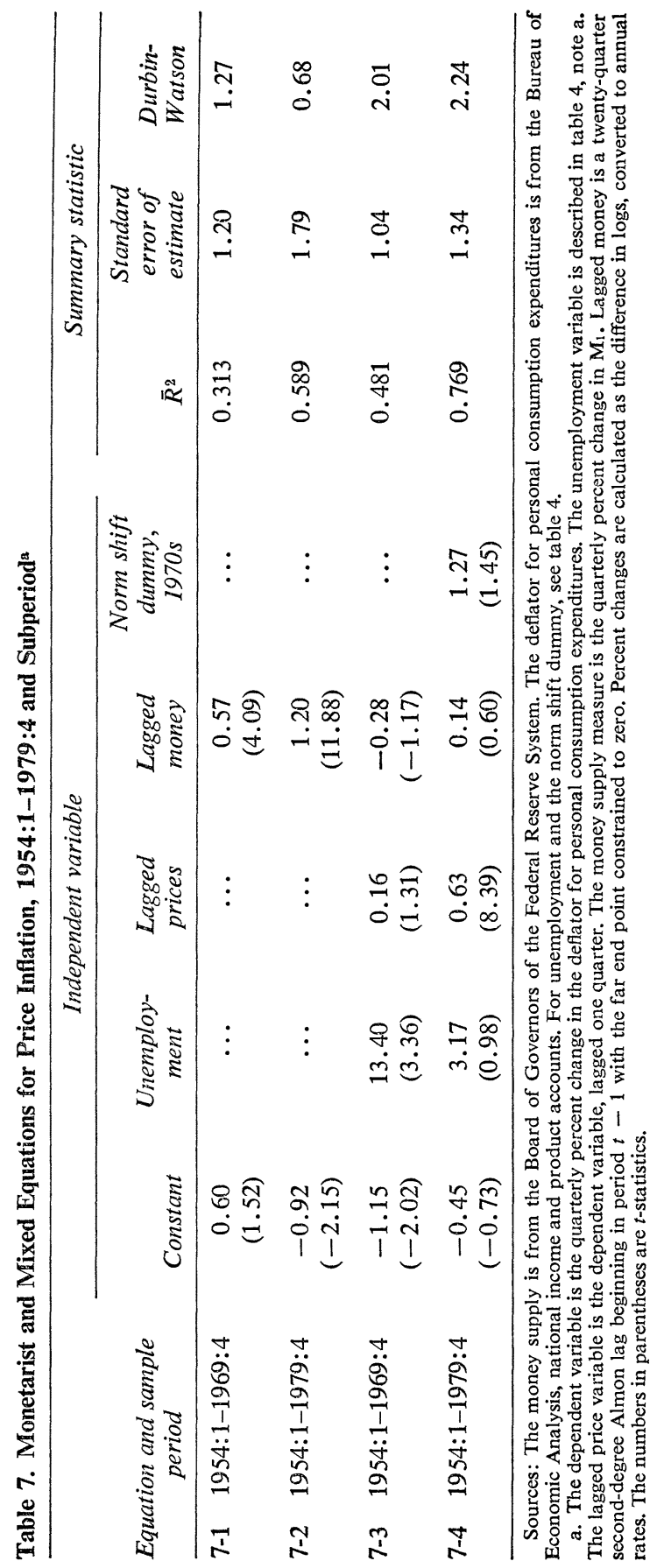


labor; discrepancies between actual and expected prices and wages determine deviations of real output and employment from their full or natural levels; and the relevant price or wage expectations are formed in a rational manner.

At the level of decisionmaking, price-taking firms adjust their output according to whether actual prices are above or below those they had expected. They also transmit this decision into their demand for labor. Workers in turn choose to work more or less according to whether wages are above or below what they had expected. Thus the prices and wages given by the market, relative to those that had been expected, determine output and employment for the period. The connection between this model of behavior and macroeconomics comes in specifying how both actual prices and wages and expected prices and wages are determined. The micro model then tells how real decisions are made given actual and expected inflation.

To make these concepts operational requires some specification of how these price and wage expectations are formed. Perfect foresight or unbiased expectations of inflation would seem natural assumptions. But these destroy the model. Perfect foresight means real output and employment would never deviate from trend, for only unanticipated prices move real variables. Unbiased expectations would lead only to random and uncorrelated deviations of real variables from their trends.

Models with rational expectations that include contracts and staggered wage setting can produce more realistic output and employment paths at the cost of rejecting the market assumptions of the new classical school. ${ }^{16}$ If lags in perception or in making real adjustments are used to rationalize any degree of departure from trend in real variables, as Lucas and Sargent have recently done, it is extremely difficult to distinguish the new classical models on the basis of how the economy performs. ${ }^{17}$ Furthermore, the point of these models for the central issue in the present paper-how inflation is related to macroeconomic performance-becomes obscured once the models have so little to say empirically about the division of nominal GNP into its price and output components.

16. See John B. Taylor, "Staggered Wage Setting in a Macro Model," American Economic Review, vol. 69 (May 1979, Papers and Proceedings, 1978), pp. 108-18.

17. See Robert E. Lucas and Thomas J. Sargent, "After Keynesian Macroeconomics," in Federal Reserve Bank of Boston, After the Phillips Curve: Persistence of High Inflation and High Unemployment, Conference Series, 19 (FRBB, 1978), pp. 49-72. 
Among models that are observable and therefore testable, it has been suggested that the relevant forecast is equivalent to the one from the best econometric model of inflation that is available at any time. It is unlikely such models would display the serially correlated errors that are needed to explain serially correlated real disturbances. And as a model of the expectations that governs individuals' behavior, this view is curiously at the other extreme from the more plausible assumption that people are ill-informed and somewhat naive about these matters. In fact, most of the new classical literature is tied to monetary models of inflation, which links them to monetarism. This is where empirical work centers. ${ }^{18}$ And this is the basis for many of the policy prescriptions that emerge from the new classical literature.

In new monetarist models-the new classical models with money as the main determinant of nominal GNP - the expected rate of inflation is given by expected growth of the money supply, which can perhaps be predicted by past money growth. Departures of inflation from the rates predicted by money give rise to departures of output and employment from their trends. The existence of only a weak and erratic relation between money and prices is essential to the new monetarist model; if the relation were too good, inflation would be forecasted correctly and real variables would be unaffected by money.

The ability of the new monetarist models to predict output and prices cannot be tested without having a specific time series that distinguishes between expected and unexpected movements in money. Robert Barro has presented some results based on his own construction of expected money. ${ }^{19}$ However, Martin Baily has raised serious questions about Barro's procedures for constructing his series and has shown that Barro's results are more easily understood in terms of conventional models that do not attempt to divide money into expected and unexpected components. ${ }^{20}$

Even if a methodology for measuring unanticipated money were agreed upon, it could not easily distinguish the hypothesis of the new

18. The most intensive empirical work has been done by Robert J. Barro. See his "Unanticipated Money, Output, and the Price Level in the United States," Journal of Political Economy, vol. 86 (August 1978), pp. 549-80.

19. Barro, "Unanticipated Money."

20. Martin N. Baily, discussion of Michael L. Wachter and Susan M. Wachter, "Institutional Factors in Domestic Inflation," in Federal Reserve Bank of Boston, After the Phillips Curve, pp. 156-63. 
Table 8. Variance of Inflation and Growth of Money and Nominal and Real GNP, by Decade, 1950-79a

Percentage points

\begin{tabular}{lccc}
\hline \multicolumn{1}{c}{ Measure } & $1950 \mathrm{~s}$ & $1960 \mathrm{~s}$ & $1970 \mathrm{~s}$ \\
\hline Money growth & & & \\
One quarter & 5.07 & 7.23 & 5.77 \\
Four quarters & 2.82 & 4.48 & 1.72 \\
Eight quarters & 2.39 & 2.71 & 0.92 \\
Nominal GNP growth & & & \\
One quarter & 51.07 & 11.68 & 17.99 \\
Four quarters & 27.27 & 4.90 & 6.58 \\
Eight quarters & 21.57 & 1.96 & 4.28 \\
Inflation & & & \\
One quarter & 9.14 & 2.10 & 7.64 \\
Four quarters & 2.31 & 1.92 & 7.33 \\
Eight quarters & 2.27 & 1.98 & 4.69 \\
Real GNP growth & & & \\
One quarter & 32.34 & 9.34 & 20.88 \\
Four quarters & 15.19 & 4.36 & 10.43 \\
Eight quarters & 10.56 & 1.61 & 6.14 \\
\hline
\end{tabular}

Sources: The money supply is from the Board of Govemors of the Federal Reserve System. All other variables are from the Bureau of Economic Analysis, national income and product accounts.

a. The money supply measure is $M_{1}$. Inflation is measured by the change in the deflator for personal consumption expenditures. The variances are calculated from percent changes of the data, seasonally adjusted at annual rates. The variances of four- and eight-quarter percent changes are calculated from nonoverlapping intervals.

monetarists from others so long as actual and unanticipated money were correlated. Most views of the economy would predict variations in money to be correlated with variations in output and employment.

To cope with this basic difficulty, I have tried to examine some of the implications of both old and new monetarism with simple, unconstrained data. Table 8 compares the variance in money growth with the variances in nominal GNP growth, price inflation (deflator for personal consumption expenditures), and real GNP growth for the decades of the 1950s, 1960s, and 1970s. The variances are calculated for growth rates over intervals of one quarter, four quarters, and eight quarters.

The common prescription of both old and new monetarism is steady monetary growth. This prescription reflects the belief that active monetary policy causes more problems than it solves. Indeed, most shocks to nominal demand and prices are argued to come from mistakes of monetary policy. Even if money has little direct relation to inflation in cyclical 
equations and little predictive power for short-run variations in inflation, maintaining steady growth of money is expected to stabilize the growth of nominal GNP, output, and prices. The variances in table 8 lend no support to these prescriptions. Compared with the 1950s or 1970s, the variance of money growth in the 1960s is greater for each interval over which it is calculated; yet this decade experienced the lowest variances in all measures of economic performance.

In the 1970s the variance of inflation is much greater than the variance of money growth. This comparison is consistent with the view that there was less monetary accommodation of price shocks in the 1970s than in the earlier periods, but not with the view that price changes were due to monetary shocks. On either old monetarist or new monetarist grounds, prices cannot be blamed on money if the variance of prices is greater than the variance of money. The latter is extremely low in this decade.

The new classical theory can also be interpreted without an explicit tie to money. In this case, the model predicts that the variance of prices and output should depend on the division of nominal GNP into expected and unexpected components. If all the variance of nominal GNP is expected, the variance of real output will be minimized and the variance of prices will be at a maximum for the given total variation of nominal GNP. In this case, the covariance between real output and prices will be near zero.

The difference between the variance of nominal GNP and the sum of the variance of real GNP and prices measures twice the covariance between real GNP and prices. For the 1950s this covariance was large and positive, ranging from 4.4 to 4.9 for the three intervals. This is consistent with the cyclical model I presented earlier or with a new classical view that much of the nominal GNP variation was unanticipated. In the 1970 s the covariance is large and negative, ranging from -3.3 to -5.6 for the three intervals. This suggests the price performance of that decade was dominated by the shocks to prices and real activity described earlier.

The most interesting case is the 1960s, for which the covariance between inflation and real growth was near zero. In terms of the new classical models, this means nominal GNP growth was largely anticipated in this decade, an inference that is supported by the low variance of nominal GNP itself. In turn this means real economic activity stayed around its equilibrium trend, and the dramatic decline in unemployment through- 
out the decade corresponded to a steady decline in the natural unemployment rate in these models. To be relevant, the concept of a natural unemployment rate must be largely invariant to changes in demand; it must be a structural characteristic of the economy, reflecting basic determinants of individuals' labor supply and how the job market is organized and functions. There is little that is distinctive or informative in the new classical models if the dramatic change in actual unemployment that took place during the 1960s is simply relabeled a decline in the natural rate.

\section{Dealing with Inflation}

I conclude that neither old monetarist nor new classical models improve the understanding of inflation provided by the model that I outlined and estimated in the first part of this paper. According to that model, the dismal record of the "discomfort index" (the sum of the unemployment rate and the inflation rate) in recent years arises from exogenous price shocks and a large shift upward in the inflation norm.

The benefits of changing an established inflation norm are hardly well established in economic theory. However, common sense suggests where all the risks and uncertainties lie. The political commitment to slow inflation is not only clear but, costs aside, undoubtedly well founded. If the inflation norm can be slowed at little cost, we should certainly do so. What are the possibilities for slowing the norm?

1. Maintain high unemployment. This promises the anti-inflation effect predicted by the cyclical Phillips curve, and by lowering experienced inflation, an eventual shift down in the norm.

2. Sustain tight fiscal and monetary policy. This produces (1). But proponents believe it offers a better payoff than (1) implies because they believe that policies act on inflation directly rather than just through their effects in creating economic slack.

3. Announce and stick to a credible restrictive policy. Proponents believe this offers a faster and better payoff than (2) because expectations of policy actions affect wages and prices.

4. Reduce prices relative to wages (without squeezing normal margins). These policies depend on the wage norm being affected by actual price inflation. 
5. Provide incentives to wage and price moderation. The broad range of tax-based incomes policies is included here.

6. Slow wages and prices by decree. This includes the range of direct restraints on wage and price behavior from guideposts through thoroughgoing controls.

I discussed the estimated costs and benefits of the high unemployment strategy (1) when I presented the simulations of table 6. I find no evidence that these costs and benefits are any different because of the particular policies pursued (2). In particular, the analysis of money presented above reaffirms that money has no independent effect on inflation.

The credibility hypothesis (3) that Fellner emphasizes is a different matter. It remains unprovable and I remain skeptical. I view it as an attempt to shift down the inflation norm. Because the norm is movable, it is an appropriate goal, consistent with the description of the inflation process that $\mathrm{I}$ have outlined. However, there is no evidence that the norm would respond to policy pronouncements. Wage setters might not respond, either because it is impossible to make such pronouncements credible or because they would ignore them even if they were believed, waiting instead for actual developments to change before altering their own behavior. Except for wages set under very long contracts, which generally call for a modest wage increase plus an escalator that frees the contractors from forecasting, other wages can be set without attention to the future over which a credible policy proposal might be supposed to have effects.

The last three possibilities for affecting the norm act directly on inflation rather than indirectly through macroeconomic policies. ${ }^{21}$ Possibility (4) above includes attempts to improve productivity growth and to reduce prices and costs through excise or payroll tax reductions or through reform of regulation or subsidy programs. Many proposals in this area are desirable on grounds of economic efficiency, but are opposed by political interests. Their quantitative potential for slowing inflation is, realistically, quite limited.

Ultimately, policymakers have a choice between using extensive slack in the economy to reduce the norm and trying to reduce it through either incomes polices that complement demand restraint or through direct controls (5) and (6). Thoroughgoing controls are too rigid, distortive, and

21. For a thorough treatment, see the articles and discussions in Arthur M. Okun and George L. Perry, eds., Curing Chronic Inflation (Brookings Institution, 1978). 
difficult to administer. They are a last resort. The practical problems that confront the design and implementation of incomes policies, especially those that include tax incentives for compliance, have been analyzed extensively. I will not attempt a summary of those issues here. The view of the inflation process that $I$ have presented in this paper makes such attempts to alter the norm both sensible and attractive as complements to macroeconomic policy. The efficient design of incomes policies should be receiving serious attention. 


\section{Comments by William Fellner}

As I see it, the concept of the wage-increase norm and of norm shifts are the main contribution of George Perry's study. My own view of Perry's position is that the changes he defines as norm shifts have indeed taken place and need to be stressed, but that they are identifiable as reflections of changes in the basic policy posture of the authorities - are at least sufficiently well identifiable to justify concentrating the analysis of Perry's problem on the underlying policy behavior. The essential characteristic of the policy shift inducing Perry's norm shifts was that, from an earlier posture based on the conception that a noninflationary price trend should be very closely approximated, policymakers moved to practices strongly motivated by the "Phillips trade-off" at the expense of price stability.

It is in the nature of these trade-off oriented practices that they do not add up to an articulate system or posture - to a credible and predictable policy-because under such practices inflationary expectations steepen and hence the trade-off requires accommodating a price trend that also tends to steepen. The result is that in order to prevent the trend from getting out of hand too rapidly the authorities occasionally engage for a while in restrictive action, thereby interrupting the steepening tendency at unpredictable stages of the process and to an unpredictable extent. What is predictable after a shift to such policies is a general tendency of the inflationary process to accelerate, and this not only shifts Perry's norms when the earlier posture is abandoned, but also renders them unstable.

The position I take in this debate ties in with what in these meetings and elsewhere I referred to as the credibility hypothesis or the valid core of rationality hypotheses in expectations theory. This is a view involving inter alia emphasis on the difference between the existence and the nonexistence of a consistent and credible policy posture. In contrast to what has sometimes been said, this is not a view attributing significance to 0007-2303/80/0243-0248\$01.0010 @ Brookings Institution 
mere declarations of intention by policymakers. A credible posture by which expectations can be conditioned obviously requires a record of consistency. But the time needed for establishing the credibility of a return to the earlier anti-inflationary posture, and for overcoming the carry-over effect of past commitments, would be much shorter than is predicted by neo-Keynesian standard models. Predictions based on standard models are strongly influenced by cost-setting and pricing practices that reflect the post-1965 policy practices and that would become adjusted again to a consistent and credible anti-inflationary policy.

\section{The Valid Core of Rational Expectations}

My interpretation is based on a conception that can be briefly described by four propositions. I do not know whether it is useful or even fair to attribute, for the sake of comparison, specific views to a recent rational expectations school in the narrower sense; to the extent that this may be useful and fair, I would say that this school rejects the third and the fourth of my propositions. Yet much of the criticism of the neoKeynesian standard approach has implied these propositions, and it seems desirable in my view that what will survive as the rational expectations approach should include all four. The propositions can be briefly summarized.

First, errors-imperfections of foresight-are responsible for the fact that the actual path of real variables is not an equilibrium path determined by the real supply prices of the inputs and by the value placed on the output obtainable from the inputs.

Second, circumstances are conceivable in which all movements of economic variables could be described as consisting of a detectable systematic component and of a stochastic error component. In this case the systematic component would be predicted by the markets (except to the extent that acquisition of such knowledge is not worth its cost). Even in this case, the stochastic component would cause deviations from an imaginary path lacking any such error component.

Third, even in the circumstances described above, the deviations from the imaginary path that is free from errors would develop not merely at the time when unexpected events occur, but also in anticipation of such events. This is because the fact that unexpected events will occur is not 
in itself unexpected, and because the public is not generally risk-neutral. This proposition contributes to the understanding of what is usually referred to as quantity adjustment rather than full price adjustment in a world of uncertainty. It contributes also to the understanding of the fact that some input commitments are made well ahead of time. From these advance commitments it follows in turn that if the error terms are serially correlated and if compensatory demand policy works with lags that are short enough, such a policy may be effective, though it does have its obvious risks.

Fourth, it is not generally useful to describe the way in which the policy variables are set by maintaining that the policy has a detectable systematic component to which a stochastic component is added. To say that a policy can usefully be so described means describing policies that belong in a special set into which some policies do and others do not belong. Take, for example, policy practices that accommodate inflationary expectations and continue to do so when these expectations steepen, yet interrupt full accommodation for a while at stages of the acceleration that do not remain the same on successive occasions. Such policy practices will keep the public guessing about a system underlying these practices, but groups of individuals will arrive at significantly different conclusions about the course of events to be expected. All such expectations will be held with little confidence: risk allowances will be large and they will differ among market participants. It is not useful to interpret such practices as containing a detectable systematic component that becomes known by the markets. What is recognized by the markets is merely a crude outline of tendencies to be expected, with a great deal of disagreement and uncertainty developing about all details relevant to decisionmaking.

\section{Unrealistic Implications of "Standard Models"}

These four propositions describe what I consider the valid core of rationality hypotheses in the theory of expectations. Acceptance of these propositions implies rejection of approaches that link wage and price movements to past movements of these variables by unchanging coefficients. These "standard approaches," illustrated by neo-Keynesian models, give an unrealistic account of the public's reaction to policies 
that do have a recognizable design, and they give an unrealistic account also of the reaction to policy practices that do not have such a design.

If a policy does have a recognizable and credible design, expectations will be formed in view of that design, and wages and prices will change accordingly. Take, for example, expectations in the era of the gold standard while that system was credible. At that time the markets clearly did not base their behavior on the expectation that the future level of an exchange rate that has moved near its upper gold point can be derived by linking the future movements of the rate with those of the past by unchanging coefficients involving an unchanging lag structure. Decisions in the markets were normally made on the assumption that the rate will not move beyond the upper gold point. Similarly, if demand-management practices were firmly expected to keep movements of the price level within narrow limits, such a design would be figured out, cost trends would take shape accordingly, and output losses, a threat that such a policy would imply, would not in fact occur.

The case for the neo-Keynesian standard approach is only seemingly better if the policy practices have no recognizable design, or if an alleged design has little credibility, with the result that shaky guesses relate at best to the crude outline of the future conduct of policy. It is hard to tell what the least unsatisfactory method is of arriving at macroeconomic generalizations in such circumstances. But if in these circumstances the public tries to see its way through its problems by rules of thumb expressing adjustments of nominal supply prices to events of the recent past, these coefficients of the neo-Keynesian type could not be expected to remain stable. Nor can the coefficients be expected to remain stable in a transition toward a detectable system or design of policy formation, that is, during a period when such a system is acquiring credibility and when the aftereffects of earlier commitments still are felt.

\section{Policy Practices and Perry's Norm Shifts}

For Perry's sample period as a whole, 1954-80, the observed instability of coefficients that leads him to introduce the concept of norm shifts develops because of the transition from a subperiod in which a pricelevel stabilizing policy design did have credibility to a subperiod with no such credible design. However, even the first subperiod seems to have 
included a few years during which the public doubted the consistency of the policy posture. These doubts were suppressed in 1958 and 1961, years that had weighted unemployment rates of 5.9 and 5.6 percent, in contrast to the other years of the 1954-65 period when the average weighted unemployment rate was 4.0 percent. The years from 1961 to about 1965 were years characterized by price stability and an average weighted unemployment rate of 4.3 percent. During the post-1965 era of accommodative laxity in policymaking and of rising prices, this unemployment rate was first reduced for a while to well below 3 percent, and it then shot up to high levels in an environment in which inflation not only has continued but has shown a pronounced tendency to steepen.

Only in the very early stages of the post- 1965 inflationary era was the short-term Phillips trade-off favorable for a few years. By now a trade-off exists probably only in the sense that the output costs of disinflating demand will have to be borne in the immediate future, while the output costs of the continued accommodation of inflationary expectations would be spread out over a period of indefinite length, starting from a lower level but growing rapidly and cumulating.

The point to be stressed here is that not only are Perry's norm shifts closely related to shifts in policy practices, but that it would be unconvincing to attribute to the norm shifts any active role-any role of a "horse" rather than of a "cart"- up to the time when, under the influence of the policy shifts, the norm shifts acquired a momentum of their own.

To illustrate with Perry's annual data, in view of the earlier relationships among the variables no autonomous norm shifts need to be assumed to explain the fact that the demand expansion resulting in the weighted unemployment rates of 1965 and 1966 (post-Korean lows of 3.2 and 2.6 percent) would have required more than the temporary 1967 restraint to stop the steepening of inflation. That restraint resulted in a 0.1 point increase for 1967 of the weighted rate (to 2.7 percent). In fact, the norms do not even seem to have reacted to the policy shift until somewhat later. Further, no autonomous norm shifts need to be assumed to explain that the reduction of the weighted unemployment rate to new lows in 1968 and 1969 ( 2.4 and 2.3 percent) would have required more than the temporary restraint of 1971 to stop an inflation that had further steepened. That restraint resulted in a rise of the weighted unemployment rate for 1971 to about the 1954-65 average level.

By the early part of the 1970s, Perry's norms had reacted to the 
changed policy posture, and this has by now produced a situation in which the shift in Perry's norms makes a temporary loss of output in the near future inevitable as compared to the situation that would exist if the earlier anti-inflationary posture had been maintained. But only to the extent that the authorities have been postponing the decision to return to that posture have Perry's norm shifts recently been given the role of the "horse" drawing the policy "cart." The problem itself developed through policy shifts that induced Perry's norm shifts and induced them with a lag. Subsequent attempts to adjust policies to norm shifts brought about by earlier policies must destabilize the economy. In such circumstances, further norm shifts develop in anticipation of further policy adjustments, and they develop amid substantial uncertainty about all relevant details of the future course of the economy.

Should this interpretation of the norm shifts in terms of changing policy postures be qualified by the effect on the norms of the recent steep increases in the price of crude materials? These increases, and the way in which the population will inevitably "accept" the resulting burden and its distribution, were largely unforeseen. Such events would, I think, cause a temporary rise in the general price level in any event. However, the size of this rise, and whether a temporary rise generates a further inflationary process or remains a one-time rise, or is subsequently reversed, does depend greatly on the demand-management practices the public expects to be put into effect. Hence, while it would be misleading to overlook the complications these events introduce into any interpretation of the observed general price movements, I do not believe that the effect of these specific price increases should be regarded as having had a lasting effect on Perry's norms independently of the demand policy practices. Thus I see no reason for modifying my suggested interpretation of Perry's norm shifts as reflecting policy shifts. 


\section{Comments by Robert J. Gordon}

Since my initial assessment of the inflation process appeared in the first issue of Brookings Papers a decade ago, George Perry and I have taken turns at these meetings in our attempts to provide quantitative explanations of the relation between inflation and both supply and demand factors. Because I disagree more with Perry's present paper than with his previous research, I find it appropriate to place both our positions within the general context of developments of the past decade. After presenting a brief summary of my own approach, I provide an alternative empirical explanation of the wage data Perry examines and then demonstrate how drastically different are the policy implications of our differing results.

At the beginning of the 1970s, the main debate concerned the thencontroversial natural rate hypothesis $(\mathrm{NRH})$ that denied the existence of a long-run trade-off between inflation and unemployment. My allegiance shifted rapidly toward NRH as I found that equations including 1970 and early 1971 data could not reject it. Most economists now accept the NRH, and Perry's present paper represents an infrequent exception. Below I suggest that Perry's "norm shift," which begins in 1970, attempts to capture the same feature of the 1970-71 data that converted me to the NRH.

\section{Three Views of the Inflation Process}

Today most disputes about inflation, and macroeconomic policy in general, focus on the speed of adjustment of inflation to shifts in nominal aggregate demand. Three main views of the inflation process compete for attention, differing mainly on this adjustment speed. First is Perry's "mainline view," which in its usual version makes wage change a function of lagged consumer price inflation, lagged wages, and a single demand vari- 
able, the inverse of an unemployment rate weighted to remove the impact of demographic shifts. ${ }^{1}$ In the new 1980 version Perry replaces the lagged wage change variable with his "norm shift" dummy, and he thus moves away from the NRH by disavowing any systematic process by which excess demand or supply is converted into a shift in the norm. In this "bootstraps" view of inflation the consequences of restrictive monetary policy are limited to movements along a fixed short-run Phillips curve until the norm changes. Perry expects that sustained slack would move the norm, but does not estimate how much slack it would take and for how much time in order to move the norm by a given amount.

What is the verdict of the mainline view on the crucial elasticity for policy purposes, the fraction of nominal demand change taking the form of price change for a given interval? The traditional mainline estimate, as summarized by Arthur Okun, is a fraction of about 10 percent during the first year after the demand change, providing a pessimistic reading of the benefits of anti-inflationary demand policy and an optimistic view of the consequences of accommodating supply shocks. ${ }^{2}$ Perry's paper is harder to characterize because the norm change eventually enters the picture. But for the first year, a wage response of about 15 percent of the nominal GNP slowdown is implied in his table 6 . He acknowledges that price responsiveness would add a little more.

At the other extreme is the second major approach to inflation, the Lucas-Sargent proposition of policy ineffectiveness (LSP). Although usually stated as a theory of output determination, LSP implies that the contemporaneous elasticity of price change to a fully anticipated change in aggregate demand is exactly unity. Since empirical work shows that anticipated demand responds quickly to changes in actual demand, LSP thus implies a prompt and complete reaction of prices to an actual decline in nominal demand growth. William Fellner's credibility hypothesis also assumes a high elasticity of price change to a "credible" shift in demand growth engineered by policymakers, but he is vague about the length of time needed for the public to conclude that a given policy shift is permanent rather than temporary.

1. George L. Perry, "Slowing the Wage-Price Spiral: The Macroeconomic View," BPEA, 2:1978, pp. 259-91.

2. Arthur M. Okun, "Efficient Disinflationary Policies," American Economic Review, vol. 68 (May 1978, Papers and Proceedings, 1977), pp. 348-52. 


\section{An Intermediate View of Inflation}

Between the mainline price-responsiveness fraction of 10 to 20 percent and the LSP fraction of 100 percent is my intermediate view. In recent research on historical quarterly data going back to 1890 , I have rejected the LSP, finding a responsiveness to anticipated demand changes during the first year that is closer to one-third than 100 percent. $^{3}$ The most important reason that I find a fraction as large as one-third, as contrasted with the smaller mainline estimate, is that my research is not limited to wage equations. Much of the impact of aggregate demand on the inflation process comes in the response of prices relative to wages. This is evident not only when separate wage and price equations are estimated, but also when a single reduced-form price equation is studied. ${ }^{4}$

\section{Main Features of the Intermediate Approach}

The underlying specification of my wage and price equations is completely symmetric. Wage change depends on lagged changes in wages, product prices, and consumer prices. The impact of aggregate demand is represented by both the level and change in the real GNP gap. Because Okun's Law continues to work so well, it is possible to replace the traditional unemployment variable with the gap, which allows the wage and price equations to be specified in a way that directly includes the elasticity of the dependent variable with respect to changes in nominal aggregate demand. The wage equation also tests for the effects of guideposts, Nixon controls, payroll taxes, the personal income tax, and the minimum wage. The price equation is set up in the same way, depending on lagged wages, the level and change of the gap, and four other shift variables-the Nixon controls, the deviation of actual productivity change from its ever-slowing

3. Robert J. Gordon, "Price Inertia and Policy Ineffectiveness," National Bureau of Economic Research, working paper (forthcoming in 1980).

4. Perry regards the estimation of equations relating prices to wages as an important research task. Nevertheless, his authorship of papers about inflation that contain only wage equations has had the unfortunate consequence of leading Okun and others to understate the responsiveness of inflation to demand shifts. 
trend, changes in the relative price of capital, and the effect of changes in the relative prices of food and energy.

The nature of the overall inflationary process can be studied by estimating this model as a single reduced-form equation, and the behavior of wages and prices can be investigated more closely by also estimating separate "structural" wage and price equations. The total elasticity of inflation to nominal demand change is about 0.15 in the first quarter and about 0.33 in the first year. These elasticities characterize the history of U.S. price change since 1892 . This demand effect is contributed by both the wage and price equations, and both the level and change in the GNP gap seem to matter in each equation.

The estimates of the inflation model also bear on several other issues. My results support Perry's conclusion that there is only a modest 25 percent pass-through from consumer prices to wages; thus the United States is far from having a fully indexed economy and has much more latitude than some European countries to consider the partial accommodation of supply shocks. Nevertheless, this 25 percent pass-through has been enough to allow the supply shocks of the 1970s partially to enter wages and largely accounts for the upward ratcheting of the rate of wage inflation between the beginning and the end of the decade.

The Nixon price controls had a major impact on the timing of inflation in the 1970s, but not on its cumulative amount. My new results indicate a larger transitory impact of the controls on both prices and wages than in some of my previous papers. A deviation of productivity from its trend has a very marked negative impact on inflation-my current estimate of the elasticity is about -0.2 , and this helps partially to explain the acceleration of inflation in 1974 and 1979 and the small increase in inflation performance in 1964-65 and 1976-77. A slowdown in the productivity trend itself enters the inflation process through the aggregate demand variable, which is defined as nominal GNP growth minus the growth in potential real GNP. Thus a slowdown of 1 percentage point in potential real growth is just as inflationary as a 1 point acceleration in nominal GNP growth.

The model can also be used to measure the impact of changes in taxes and in the minimum wage. The reduced-form price equation suggests very little impact of the payroll tax on inflation. Overall the employee share is borne entirely by employees, and the employer share about one-third each by wages, profits, and prices. Because there is a small amount of 
forward shifting of the personal income tax, there appears to be no antiinflationary mileage in substituting the personal tax for the payroll tax. The inflationary effect of the minimum wage seems robust but relatively minor; the series of minimum-wage hikes during 1977-81 adds at most 0.5 percentage point to the price level. ${ }^{5}$

\section{An Empirical Comparison}

Much of Perry's discussion of inflation during the 1970s revolves around the special nature of the period between 1970 and 1975, and around the role of the two "norm shift" dummies for the 1950s and 1970s. While Perry offers no explanation for changes in the norm, he nevertheless argues that these dummies are indispensable for an empirical explanation of wage change. Because of space limitations, my discussion of his empirical results is confined to a demonstration that wage changes can be explained without the 1970s norm shift. I do find that his 1950 s norm shift is quite robust, and I discuss the implications of this finding below.

In my table 1, column 1 displays an equation similar to Perry's for the full 1954-80 period, using my data and a version of his slope shift dummy, the ratio of the 1970s norm shift dummy to the unemployment rate. This switch, including the early quarters of 1970 , produces a virtually horizontal Phillips curve for the 1970s. However, Perry argues against this interpretation and it is not essential to the comparison with my alternative specification.

Column 2 adds a dummy for the Nixon controls program. This dummy is constructed to sum to zero and thus forces the effect of program termination to cancel its initial impact. The Nixon dummy aids in the explanation of the early 1970s and reduces somewhat the coefficient on the consumer price index (which otherwise carries the full burden of explaining the 1974 wage acceleration).

Column 3 presents my preferred specification, with a few modifications to aid in the comparison with Perry's results. The tax and minimum wage variables have been omitted from the equations to simplify the table. In addition to the change in nominal GNP and the lagged GNP gap (the latter measured to indicate a recession as a negative gap), on line 7 a gap

5. With the exception of the Nixon controls variable, the effects discussed in the previous two paragraphs are omitted from table 1 to save space. 
Table 1. Estimated Equations for Wage and Price Inflation, Alternative Models, 1954:1-1980:1

\begin{tabular}{|c|c|c|c|c|c|}
\hline \multirow[b]{2}{*}{$\begin{array}{l}\text { Independent variable or } \\
\text { summary statistic }\end{array}$} & \multicolumn{4}{|c|}{ Wage equation } & \multirow{2}{*}{$\begin{array}{l}\text { Reduced- } \\
\text { form price } \\
\text { equation } \\
\text { (5) }\end{array}$} \\
\hline & $\begin{array}{l}\text { Perry's } \\
\text { equation } \\
(I)\end{array}$ & $\begin{array}{l}\text { Effect of } \\
\text { controls } \\
(2)\end{array}$ & $\begin{array}{l}\text { Effect o } \\
\text { wage it } \\
(3)\end{array}$ & $\begin{array}{c}\text { lagged } \\
\text { lation } \\
\quad(4)\end{array}$ & \\
\hline \multicolumn{6}{|l|}{ Independent variable } \\
\hline 1. Constant & $\begin{array}{l}-0.25 \\
(-0.39)\end{array}$ & $\begin{array}{l}-0.25 \\
(-0.41)\end{array}$ & $\begin{array}{c}2.76 \\
(5.36)\end{array}$ & $\begin{array}{l}2.80 \\
(5.94)\end{array}$ & $\begin{array}{l}0.85 \\
(2.96)\end{array}$ \\
\hline 2. Unemployment & $\begin{array}{l}14.81 \\
(4.41)\end{array}$ & $\begin{array}{l}15.53 \\
(4.71)\end{array}$ & $\ldots$ & ... & $\ldots$ \\
\hline 3. Lagged unemployment & $\begin{array}{l}-3.30 \\
(-1.06)\end{array}$ & $\begin{array}{l}-3.39 \\
(-1.11)\end{array}$ & $\ldots$ & ... & ... \\
\hline 4. Slope shift, 1970s & $\begin{array}{l}-8.64 \\
(-2.32)\end{array}$ & $\begin{array}{l}-9.87 \\
(-2.68)\end{array}$ & $\cdots$ & $\cdots$ & $\cdots$ \\
\hline $\begin{array}{l}\text { 5. Growth of aggregate } \\
\text { demand }\end{array}$ & $\ldots$ & $\cdots$ & $\begin{array}{c}0.08 \\
(3.39)\end{array}$ & $\begin{array}{l}0.08 \\
(3.31)\end{array}$ & $\begin{array}{c}0.17 \\
(5.78)\end{array}$ \\
\hline 6. Lagged real GNP gap & $\ldots$ & $\cdots$ & $\begin{array}{l}0.25 \\
(3.90)\end{array}$ & $\ldots$ & $\begin{array}{c}0.22 \\
(3.89)\end{array}$ \\
\hline 7. Gap shift, 1970 s & $\ldots$ & $\ldots$ & $\begin{array}{l}-0.11 \\
(-1.03)\end{array}$ & $\begin{array}{l}-0.06 \\
(-0.63)\end{array}$ & $\begin{array}{c}0.09 \\
(0.68)\end{array}$ \\
\hline 8. Adjusted lagged gap & $\ldots$ & $\ldots$ & $\ldots$ & $\begin{array}{l}0.23 \\
(3.92)\end{array}$ & $\ldots$ \\
\hline 9. Lagged CPI inflation & $\begin{array}{l}0.36 \\
(6.81)\end{array}$ & $\begin{array}{c}0.28 \\
(4.46)\end{array}$ & $\cdots$ & $\cdots$ & $\cdots$ \\
\hline $\begin{array}{l}\text { 10. Lagged CPI inflation } \\
\text { minus lagged wage } \\
\text { inflation }\end{array}$ & $\cdots$ & $\ldots$ & $\begin{array}{c}0.22 \\
(2.67)\end{array}$ & $\begin{array}{c}0.22 \\
(2.69)\end{array}$ & $\ldots$ \\
\hline 11. Food and energy effect & $\ldots$ & $\cdots$ & $\ldots$ & ... & $\begin{array}{c}0.38 \\
(2.92)\end{array}$ \\
\hline 12. Guidepost dummy & $\begin{array}{l}-0.25 \\
(-0.63)\end{array}$ & $\begin{array}{l}-0.32 \\
(-0.85)\end{array}$ & $\begin{array}{l}-0.40 \\
(-1.04)\end{array}$ & $\begin{array}{l}-0.41 \\
(-1.19)\end{array}$ & $\begin{array}{l}-1.17 \\
(-2.65)\end{array}$ \\
\hline 13. Nixon controls dummy & $\ldots$ & $\begin{array}{l}-0.96 \\
(-2.28)\end{array}$ & $\begin{array}{l}-1.46 \\
(-3.06)\end{array}$ & $\begin{array}{l}-1.45 \\
(-3.08)\end{array}$ & $\begin{array}{c}-3.77 \\
(-7.29)\end{array}$ \\
\hline 14. Norm shift, $1950 \mathrm{~s}$ & $\begin{array}{c}0.80 \\
(2.58)\end{array}$ & $\begin{array}{c}0.76 \\
(2.51)\end{array}$ & $\begin{array}{c}0.68 \\
(2.06)\end{array}$ & $\ldots$ & $\ldots$ \\
\hline 15. Norm shift, $1970 \mathrm{~s}$ & $\begin{array}{l}4.35 \\
(3.94)\end{array}$ & $\begin{array}{c}5.04 \\
(4.49)\end{array}$ & $\begin{array}{c}1.01 \\
(0.92)\end{array}$ & ... & ... \\
\hline $\begin{array}{l}\text { 16. Lagged wage inflation, } \\
1954-67^{\mathrm{b}}\end{array}$ & $\ldots$ & $\ldots$ & $\begin{array}{c}0.30 \\
(2.27)\end{array}$ & $\begin{array}{c}0.30 \\
(2.31)\end{array}$ & $\cdots$ \\
\hline $\begin{array}{l}\text { 17. Lagged wage inflation, } \\
1968-80^{\mathrm{b}}\end{array}$ & $\cdots$ & $\cdots$ & $\begin{array}{c}0.45 \\
(2.44)\end{array}$ & $\begin{array}{c}0.60 \\
(8.26)\end{array}$ & $\cdots$ \\
\hline 18. Lagged price inflation ${ }^{\mathrm{e}}$ & $\ldots$ & $\ldots$ & $\cdots$ & $\cdots$ & $\begin{array}{c}0.76 \\
(9.05)\end{array}$ \\
\hline
\end{tabular}


Table 1 (continued)

\begin{tabular}{|c|c|c|c|c|c|}
\hline \multirow[b]{2}{*}{$\begin{array}{l}\text { Independent variable or } \\
\text { summary statistic }\end{array}$} & \multicolumn{4}{|c|}{ Wage equation } & \multirow{2}{*}{$\begin{array}{l}\text { Reduced- } \\
\text { form price } \\
\text { equation } \\
(5)\end{array}$} \\
\hline & $\begin{array}{l}\text { Perry's } \\
\text { equation } \\
\quad(I)\end{array}$ & $\begin{array}{l}\text { Effect of } \\
\text { controls } \\
\text { (2) }\end{array}$ & $\begin{array}{l}\text { Effect } \\
\text { wage } \\
\text { (3) }\end{array}$ & $\begin{array}{l}\text { gged } \\
\text { ion } \\
(4)\end{array}$ & \\
\hline \multicolumn{6}{|l|}{ Summary statistic } \\
\hline$\vec{R}^{2}$ & 0.82 & 0.83 & 0.85 & 0.84 & 0.86 \\
\hline Standard error of estimate & 0.90 & 0.88 & 0.87 & 0.87 & 1.09 \\
\hline Durbin-Watson & 2.11 & 2.20 & 2.17 & 2.16 & 1.79 \\
\hline
\end{tabular}

Sources: The average hourly earnings index and the weighted unemployment rate are the same series as used by George Perry. Price and GNP data are from the U.S. Bureau of Economic Analysis, national income and product accounts. The consumer price index is from the U.S. Bureau of Labor Statistics.

a. The dependent variable in the wage equations is the same as that used by Perry. The dependent variable in the price equations is the quarterly percent change in the GNP deflator, multiplied by four. The unemployment and lagged unemployment variables are the inverse of Perry's weighted unemployment rate, as in Perry's paper. The slope shift variable is the 1970s norm shift dummy divided by the weighted unemployment rate. Aggregate demand growth is measured by the annualized percent change of nominal GNP minus the annualized percent change in potential real GNP. The potential GNP series is the QPOT1 series provided by Jeffrey M. Perloff and Michael L. Wachter that is described in their "A Production Function-Nonaccelerating Inflation Approach to Potential Output: Is Measured Potential Output Too High?" in Karl Brunner and Allan H. Meltzer, eds., Three Aspects of Policy and Policymaking: Knowledge, Data and Institutions, Carnegie-Rochester Conference Series on Public Policy, vol. 10 (Amsterdam: North-Holland, 1979), pp. 113-63. The lagged real GNP gap is the one-quarter lagged ratio of actual to potential real GNP, minus one, and the 1970s gap shift is this variable times the 1970 norm shift dummy. In column 4 the lagged gap variable is adjusted by subtracting 2.5 percent from potential GNP between 1954 and 1961 . The lagged CPI variable is the sum of quarterly changes in the CPI in quarters $t-1$ through $t-4$, and the "lagged CPI inflation minus lagged wage inflation" variable subtracts the values of the dependent variable for the same quarters. The food and energy effect is the difference between the deflators for personal consumption expenditures including and excluding food and energy. The guidepost dummy is similar to Perry's. The "Nixon controls" dummy is equal to 0.67 during the six quarters from 1971:3 to $1972: 4$ and to -1.00 from 1974:2 to $1975: 1$. The norm shift dummies are identical to Perry's. The numbers in parentheses are $t$-statistics.

b. These coefficients are the sum of a set of twelve lagged coefficients estimated to lie along a thirddegree polynomial with the far end point constrained to zero.

c. Same as note $b$, except that there are twenty lagged coefficients.

shift is introduced that is exactly analogous to the slope shift on line 4. An important difference is line 10, where the CPI effect is measured net of wage change (this does not alter the fit or the coefficients on the norm shift dummies but allows the explanation of the 1965-70 acceleration of inflation to be "carried" by the lagged wage terms rather than by the CPI itself-this variable is thus more directly a measure of the response of wages to supply shocks). These shifts in specification are sufficient to reduce the 1970s norm shift dummy to statistical insignificance.

One interpretation of the significance of the 1950s norm shift in column 3 is that the GNP gap is mismeasured. One implausible feature of the potential output series of Jeffrey Perloff and Michael Wachter that I use is that there was no excess demand in 1956 or 1957, and thus the equation cannot fully explain the acceleration of wage change in those years. Column 4 adjusts the lagged gap variable by subtracting 2.5 percent from 
Table 2. Simulated Effect on Wage and Price Change of a Five Percent Instead of a Ten Percent Growth in Aggregate Demand, Selected Quarters, 1980:2-1939: 4a

Percentage points

\begin{tabular}{ccc}
\hline $\begin{array}{c}\text { Year and } \\
\text { quarter }\end{array}$ & $\begin{array}{c}\text { Effect on wage } \\
\text { change }\end{array}$ & $\begin{array}{c}\text { Effect on price } \\
\text { change }\end{array}$ \\
\hline $1980: 4$ & -1.09 & -1.75 \\
$1981: 4$ & -1.72 & -3.38 \\
$1982: 4$ & -2.05 & -4.62 \\
$1989: 4$ & -2.52 & -5.35 \\
\hline
\end{tabular}

Source: Derived from equations in table 1 , columns 4 and 5 .

a. The growth in aggregate demand is the difference between the annualized growth rates of nominal GNP and potential real GNP, the same variable listed in table 1 , line 5 .

potential GNP between 1954 and 1961 and also drops the insignificant 1970s norm shift dummy. The resulting equation has the lowest standard error of all four wage equations in table 1.

Both wage equations in columns 3 and 4 split the lagged wage variable at the beginning of 1968 . Thus the phenomenon that Perry is attempting to capture in his norm shift variable for the 1970s is partially incorporated in the shifting coefficients on lagged wages. As the rational expectations theorists have shown, the weight of a lagged variable in the formation of expectations should depend on the nature of the process itself. An explanation of wage change based on shifting coefficients on past inflation was explored in one of my early papers. ${ }^{6}$

For contrast, a simple reduced-form inflation equation is presented in column 5. This displays about the same influence of the GNP gap as the wage equation but no evidence at all of a declining importance of the gap in the 1970s. The influence of demand growth is more important, as are both the guidepost and Nixon control dummies. For the NRH to be valid, the coefficients of the nominal aggregate demand variable and the lagged price should add up to unity, and the sum in this column is 0.93 .

The differing policy implications of columns 4 and 5 are summarized in table 2 above. What difference does it make for wage and price change if two alternative constant growth rates are postulated for the aggregate demand variable between 1980:2 and 1989:4—say, 5 as opposed to 10 percent? The price equation exhibits a prompt response of price change to the more restrictive demand policy, with most of the adjustment com-

6. Robert J. Gordon, "Wage-Price Controls and the Shifting Phillips Curve," $B P E A, 2: 1972$, pp. 404-06. 
plete by late 1982. At that point the GNP gap is 5 percent more negative. By 1989 that difference gradually shrinks to 0.3 percent. But the wage equation exhibits much more sluggish behavior. Because wage change by 1989 has only slowed down by half of the drop in demand growth, the GNP gap becomes steadily more negative throughout the decade. This pessimistic verdict on the consequences of restrictive demand policy reflects both the smaller demand coefficients in the wage equation and the fact that the conditions for the NRH are not satisfied.

For years now policymakers have been told that a restrictive demand growth policy would have little impact on inflation and would impose an enormous cost in the form of lost output. The drastic difference between the implications of the two columns of table 2 suggests the importance of careful quantitative estimates of the responsiveness of inflation to changes in demand growth. I view all the wage equations in table 1 as presenting an incomplete view of the inflation process and as sending unrealistically pessimistic signals to policymakers. While the price simulation may look surprisingly optimistic, it reflects an experiment that has not yet been carried out, and there is no other basis on which to judge its effects. 


\section{General Discussion}

Perry's wage-norm concept generated a spirited discussion. James Duesenberry found the norm useful because it rejects an unchanging and mechanical link of today's inflation with the past. He characterized the norm as the wage increase a personnel manager would want to give if his firm had no special employment needs or problems. That wage increase would be dictated by what is happening in other companies, and, moreover, microeconomic research is probably needed to improve the understanding of how the norm changes at different times. Martin Baily believed the norm model correctly disputes the empirical foundation of the natural rate hypothesis, and especially the way the natural rate has been estimated using lagged inflation variables. Robert Hall thought Perry's formulation was helpful in understanding the defects of models that make inflation largely expectational, because these were refuted by their own predictions of serially uncorrelated real disturbances, and simple autoregressive structures for wages, because these have yielded unstable empirical results with the autoregressive structure vanishing altogether in the 1970s.

Other panelists were more critical. Christopher Sims argued that Perry's result mainly documents the fact that most inflation is not explained by the conceptual framework of his wage equations. He questioned Perry's conceptualization of the norm as a component of inflation that could be shifted without allocative consequences, and argued that one could not reach policy conclusions from estimated structural equations of this type. William Nordhaus preferred the norm concept to previous work that specifies a simple link to past inflation, but argued that the concept is not useful until it is possible to establish how the norm is formed. In Perry's formulation, it simply documents our ignorance of this important problem.

While Nordhaus found it a weakness of Perry's norm that it resembled 
discussions in Europe of unexplained ratchets in the inflation rate, Robin Marris thought that an important point in favor of the norm is that it has widespread applications. He related it to work done earlier by Perry and others on wage explosions in the late 1960s and early 1970s in most industrial countries.

Marris and others found the norm concept has clear policy implications for slowing inflation even if one could not explain exactly how the norm had shifted upward. Thomas Juster and John Shoven reasoned that the norm concept clarified both analytically and empirically the need for direct attempts to reduce the ongoing inflation rate through some form of incomes policy. However, Nordhaus objected that Perry's formulation provides no guidance about the costs and benefits of alternative disinflation remedies such as William Fellner's proposal for credible sustained economic restraint. Nordhaus suspected that if the norm could be explained, it might have little or no expectational component, but he regarded this as the critical object for research. Marris pointed out that incomes policies historically carry large political costs and that the decision to use them always weighs that political cost against the economic cost of producing slack or permitting inflation to continue. He noted that the present government in the United Kingdom is adopting something like a Fellner approach in the belief that its political costs will be tolerable.

Hall interpreted Perry's results on monetarism as showing that monetary changes have large effects on output and only minor effects on prices in the short run, a result that is consistent with Robert Barro's recent empirical work. But he found that these results do not refute rational expectations models because they do not test them specifically. Baily responded that a key prescription of rational expectations models is precisely that monetary policy could slow inflation without a major cost in output and employment. Sims agreed with Perry that inflation in the 1970s cannot be explained as a reaction to the conduct of aggregate demand management or, in particular, monetary policy. But he believed a more sophisticated rational expectations view that treated energy as a macroeconomic variable might explain the stagflation effects of OPEC price increases.

Benjamin Friedman observed that Fellner's "valid core" of rational expectations, which he had outlined in his discussion, consists of propositions with which almost any economist would agree. Moreover, it does not include the more debatable propositions usually associated with ra- 
tional expectations macro models. James Tobin disagreed with Fellner's characterization that the public perceived a shift in policy in the 1960s from an orientation toward stable prices to a conscious attempt to move along a Phillips curve. Tobin argued that the guidelines policy of 196165 had been devised precisely because policymakers considered it unacceptable to have a recovery that was accompanied by inflation. The inflation of 1966-69 was not in fact the consequence of deliberate policy to gain employment at the expense of higher inflation. It was the result of President Johnson's escalation of the Vietnam War and his rejection of the fiscal advice of his Keynesian economists. The episode probably merely reinforced the association in the public's mind between war and inflation.

Commenting on Robert Gordon's discussion, Nordhaus noted that the greater cyclical response of prices relative to wages that Gordon emphasized is a purely transitory difference. Because Gordon's formulation makes price changes responsive to changes in employment or unemployment, any gains achieved from that source when the economy went into recession are reversed as soon as the economy returns to its initial utilization rate. 